\title{
Forecasting Volatility Stock Return: Evidence from the Nordic Stock Exchanges
}

\author{
Nikolaos Dritsakis ${ }^{1} \&$ Georgios Savvas ${ }^{2}$ \\ ${ }^{1}$ Professor, Department of Applied Informatics, School of Information Sciences, University of Macedonia, \\ Thessaloniki, Greece \\ ${ }^{2}$ Post-Graduate Student, Master of Science in Applied Informatics, Department of Applied Informatics, School of \\ Information Sciences, University of Macedonia, Greece \\ Correspondence: Georgios Savvas, Department of Applied Informatics, School of Information Sciences, \\ University of Macedonia, Thessaloniki, Greece. Tel: 306-987-281-898. E-mail: mai16058@uom.edu.gr
}

Received: November 19, 2016

Accepted: December 15, 2016

Online Published: January 10, 2017

doi:10.5539/ijef.v9n2p15

URL: http://dx.doi.org/10.5539/ijef.v9n2p15

\begin{abstract}
The purpose of this study is to explore the volatility and secondary effects in the four Nordic stock exchanges of Norway: Oslo Børs Linked all-share index AXLT Denmark: OMX Copenhagen 20, Sweden: OMX Stockholm 30 and Finland: OMX Helsinki 25. Keeping in mind that there is an ARCH effect in the returns of the four stock exchanges, we move on to the evaluation to the evaluation of models ARCH (q), GARCH (p, q) אal GARCH-M (p, q). Evaluating the parameters became possible through the use of the maximum likelihood method using the BHHH algorithm of (Berndt et al., 1974) and the three distributions (normal, t-Student, and the Generalized normal distribution GED). The results of this study indicate model ARMA $(0,1)-\mathrm{GARCH}-\mathrm{M}(1,1)$ with $\mathrm{t}$-student distribution as the appropriate one to describe the returns of the all Nordic stock exchanges except that of Sweden, where model ARMA(0,3)-GARCH-M(1,1) describes it best. Lastly, for forecasting the models $\operatorname{ARMA}(0,1)$-GARCH-M(1,1) and ARMA(0,3)-GARCH-M(1,1) of the current stock exchanges we use both the dynamic and static process. The results of this study indicate that the static process forecasts better than the corresponding dynamic.
\end{abstract}

Keywords: stock returns, GARCH models, forecasting volatility, Nordic stock exchanges, BHHH algorithm

\section{Introduction}

In recent years the financial world is in a serious instability. Modeling financial series is a complex matter for most economists. This complexity derives not only from the various financial market products (interest rate, exchange rates, reserves etc.) but also from the effect of political incidents. These incidents create volatility in time-series, resulting to the difficulty of creating various stochastic models. Assets evaluation becomes possible using their return, which is conventionally defined as the logarithmic price changes, which is close to the relative price change. This return is depicted as follows:

$$
R_{t}=\ln \left(X_{t} / X_{t-1}\right)
$$

where $R_{t}$ is a financial asset with value $X_{t}$ at time $t$ and $X_{t-1}$ at time $t-1$. The return is scale-free, which facilitates comparisons between assets.

The theory of option pricing is an important topic in the financial literature. The Black, and Scholes (1973) study was the beginning of the European-style purchase options. Consequently it was discovered that the prices of Black and Scholes models differ from the market prices, therefore the literature for evaluating the purchase options formulated a series of theoretical models designed to capture these empirical biases. Various empirical studies related to the price dynamics of current assets, indicated that the assets features in time is the volatility, the non-normality and leverage effect, thus, they should be taken into consideration in financial data. Therefore the various models and developed techniques should incorporate some or all of the above properties.

As previously stated volatility clustering has been used instead of a constant variable in volatility functions depended on the asset value and time. Furthermore time-series are regarded as a stochastic process which can be analysed in two elements:

$$
R_{t}=m_{t}+u_{t}
$$




$$
u_{t}=\sigma \varepsilon_{t}
$$

Where $m_{t}$ is a predictable process, and $u_{t}$ is a nondeterministic process driven by a random noise $\varepsilon_{t}$ is iid with zero mean value and variance one.

GARCH symmetrical models cannot define asymmetry and leptokurtosis in financial data. For this particular reason the GARCH-in-mean model is used in this study, which adds a heteroscedastic term in the equation mean which is determined as a risk premium and incorporates a type of assymetry.

The research on the return and volatility of the Nordic stock markets was carried out for the following reasons:

- $\quad$ There is a strong financial cooperation between those countries.

- The monetary and tax systems of the researched markets are similar and a close association exists between these countries.

- $\quad$ These four Nordic countries have similar industries, therefore their stock markets display a strong correlation.

- $\quad$ They have common trade partners.

- $\quad$ Their stock markets opening and working times coincide.

This research differs from past ones which researched the Nordic market for the following reasons:

1) The past studies of researching volatility and the relationship between the Nordic markets used data from 1988 to 1994 Booth et al. (1997), while Hyytinen (1999) used weekly data and only for three markets (Finnish, Norwegian and Swedish market) from 1983 to 1997 . The expansion of data in this study and the conclusions analysis are important for investors who want to diversify their portfolios.

2) The results of this study indicate that every one of these markets are described better from model ARMA(0,1)-GARCH-M(1,1) with t-Student distribution, unlike Booth's et al. (1997) study which uses the EGARCH asymmetric model, and Hyytinen's (1999) which uses the TGARCH asymmetric model for Sweden and GARCH symmetric models for Finland and Norway.

3) Furthermore, the results of this study agree with those of Booth's et al. (1997) that the volatility in the four markets indicate that ill news are stronger than good news. The research on the returns and the volatility of secondary effects in the Nordic markets dictate the enactment of a common Nordic stock market, to create the fourth bigger stock market in Europe after the ones of London, Paris and Frankfurt.

In this paper a short introduction of financial return is presented in section 1. The rest of this paper is as follows: section 2 contains the literature review, section 3 presents the methodological analysis, section 4 describes the data and the descriptive statistics, in section 5 the empirical results of this study are given, while in section 6 the forecasting results are presented. Last but not least, in section 7 the conclusions of this study are given.

\section{Literature Review}

Time-series performance analysis has troubled financial researchers in recent years. One of the first evaluation tries was conducted from Eun and Shim (1989) when they researched the daily returns of the Australia, Hong Kong, Japan, France, Canada, Switzerland, Germany, the United States and Britain stock exchanges. The results of their study indicated that there are substantial interdependencies among these markets, most of which are with the U.S. stock market. European and Asian stock exchange dependencies are strong but with one day delay.

Hamao, et al. (1990) used daily data from April 1985 to March 1988 from three stock indexes, Nikkei 225 of the Japan stock exchange, FTSE of the Great Britain stock exchange and S \& P 500 of the U.S.A. stock exchange. Using model GARCH-M(1,1) they resulted that Nikkei 225 is influenced both from S \& P 500 and FTSE, while FTSE is influenced only from S \& P 500.

Booth et al. (1997) in their study used a multivariate exponential generalized autoregressive conditionally heteroscedastic $(\mathrm{EGARCH})$ model to research the interaction of the four Scandinavic stock markets in period May $2^{\text {nd }} 1988$ to June $30^{\text {th }} 1994$. The results of their study indicate that volatility in the asymmetric model used is being more pronounced for bad than good news.

Hyytinen (1999) studies the development of conditional volatility of returns in three Scandinavian countries (Finland, Norway and Sweden) using weekly data from 1983-1997. The results of the paper shown that the asymmetric EGARCH model is most suitable for Sweden's data whereas the symmetric model GARCH $(1,1)$ is more preferable for the other two countries.

$\mathrm{Ng}$ (2000) examined the magnitude and changing nature of volatility spillovers from Japan and the US to six 
Pacific-Basin equity. He used indexes Hang Seng of Hong Kong, the Korean Composite Stock Price Index, the Kuala Lumpur Stock Exchange Composite Index (Malaysia), the Stock Exchange of Singapore All Share Index, the Taiwan Stock Exchange Weighted Price Index, the Stock Exchange of Thailand Index, the Tokyo Stock Price Index, and the Standard and Poor's 500 Index. The results of his study indicated that four of six Pacific Basin Region stock exchanges are influenced less than $10 \%$ weekly from a change in the returns of Japan and USA stock markets.

Lee (2004) in his study researches the transition mechanism of the stock market return via wavelet analysis. He used the wavelet analysis instead of $\mathrm{CARCH}$ models, claiming that his analysis researches the potential and possible interactions of international stock markets. Using daily data from the USA and Korean stock exchange he resulted that developed markets volatility one-way influence the developing ones.

Trang Nha Le and Makoto Kakinaka (2010) researched volatility and secondary effects in three major stock markets, such as these of Japan, USA and China, as well as two emerging ones of Indonesia and Malaysia from the years 2005 to 2007. Using CARCH models they found that there are significant mean spillover effects from the three major markets to the two emerging markets. Furthermore they found that the size of the USA stock market influence upon the emerging ones is greater than those of Japan and China. Lastly, the results of their study indicated that the USA stock market influence upon the Indonesian market is greater than in the Malaysian.

Prashant (2014) researched the return and volatility among the indexes BSE and DJIA of India and US Stock Markets respectively. To do this he used model GARCH-BEKK from January 2, 2012 to April 4, 2014. His study results indicated that DJIA index exercises more influence on BSE in terms of shocks and volatility transmission . Furthermore, he proved that total volatility is greater in the USA stock exchange.

Thenmozh and Chand (2016) in their study showed that forecasting returns based on global reserves attributed better in day trading both in emerging and major markets. Forecasting the returns, the researchers used vector regression for six stock markets, namely those of USA (Dow Jones, S\&P500), UK (FTSE-100), India (NSE), Singapore (SGX), Hong Kong (Hang Seng) and China (Shanghai stock exchange) for the period 1999-2011. The empirical analysis shows that models with other global market price information outperform forecast models based merely on auto-regressive past lags and technical indicators.

\section{Methodology}

Uncertainty plays an essential role in economic analysis and is usually measured with volatility. There are time-series, mainly financial, who display periods of mass volatility. These time-series experience periods with dramatic increases and decreases, during which their variance is varying over time. Therefore, researchers can test the variance of this particular time-series in the varying period, namely the conditional variance. Hence, we can describe the time-series models with conditional variance as conditional heteroscedastic models. Engle (1982) suggested that the varying variance can be described through an autoregressive model depending on its former values. Specifically this model is described as Autoregressive Conditional Heteroscedastic Model, known as ARCH model.

Therefore, based on a structured model, variance can be measured and forecasted. Variance forecasting is crucial to pricing and risk management. In various studies, several variance models have been suggested to be able to include the features of financial time-series efficiency or an asset. The features of an asset's efficiency that researchers acknowledge are as follows:

- The variance of an asset develops with time, in a constant way.

- Periods of great movement in prices, alternate with periods where prices don't move. This feature is known as volatility clustering.

- The variance of an asset does not tend to infinity.

- $\quad$ There is an asymmetric movement in variance.

- Usually, extreme kurtosis or fat-tailedness is observed in variance.

\subsection{ARCH-GARCH Varying Models}

ARCH-GARCH varying models are consisted of two equations. The first one (mean equation) describes the data over another variable (if present) adding the standard error. The second one (covariance equation) define the evolution of conditional covariance of the error, from the mean equation as a variance of the past conditional covariance of the lagged error.

The mean equation in ARCH - GARCH models is depicted as: 


$$
R_{t}=\mu+\varepsilon_{t}(\text { ARCH model })
$$

The error term $\varepsilon t$ in a simple mean equation is linear unrelated, but not time-independent.

$$
R_{t}=\mu+\beta \sigma_{t}^{2}+\varepsilon_{t}(\mathrm{GARCH} \text { model })
$$

Covariance equation in $\mathrm{ARCH}-\mathrm{GARCH}$ models is depicted as:

$$
\sigma_{t}^{2}=\omega+\sum_{i=1}^{q} a_{i} \varepsilon_{t-i}^{2} \text { (ARCH model) }
$$

The non-linear dependency that the error term $\varepsilon t$ depicts can be described through the use of squared lagged errors Parameters $\omega, \alpha_{1}, \alpha_{2}, \ldots, \alpha_{\mathrm{q}}$ are unknown and because covariance is a positive number, meaning that the positive terms are in place, where $\omega>0$ and $\alpha_{1}, \alpha_{2}, \ldots, \alpha_{\mathrm{q}} \geq 0$.

$$
\sigma_{t}^{2}=\omega+\sum_{i=1}^{q} \alpha_{i} \varepsilon_{t-i}^{2}+\sum_{j=1}^{p} \beta_{j} \sigma_{t-j}^{2} \text { (GARCH model) }
$$

We hypothesize that, for $\mathrm{p} \geq 0$ and $\mathrm{q}>0$, the parameters are unknown and because of covariance being a positive number the following conditions are in place $\omega \geq 0$ and $\alpha_{i} \geq 0$ for $i=1, \ldots, q$ and $\beta_{i} \geq 0$ for $j=1, \ldots, p$

$\operatorname{ARCH}(1,1)$ model is depicted as:

$$
\sigma_{t}^{2}=\omega+\alpha_{1} \varepsilon_{t-1}^{2}
$$

where $\omega \geq 0$ and $\alpha_{i} \geq 0$ for the positive number of $\sigma_{t}^{2}$

$\operatorname{GARCH}(1,1)$ model is depicted as:

$$
\sigma_{t}^{2}=\omega+\alpha_{1} \varepsilon_{t-1}^{2}+\beta_{1} \sigma_{t-1}^{2}
$$

where $\omega \geq 0, \alpha_{\mathrm{i}} \geq 0$ and $\beta_{\mathrm{i}} \geq 0$ for the positive number of $\sigma_{\mathrm{t}}^{2}$

\subsection{ARCH-GARCH Models Features}

ARCH - CARCH model according to Engle(1982) is based on the two following hypothesis:

- The error term $\varepsilon_{t}$ in a simple mean equation $\left(y_{t}=\mu_{t}+\varepsilon_{t}\right)$ is linear unrelated, but not time-independent.

- The non-linear dependency that the error term $\varepsilon_{t}$ depicts can be described through the use of squared lagged errors

\subsection{ARCH-GARCH Models Test and Evaluation}

Evaluation of ARCH-GARCH models is possible through the use of maximum likelihood method. The logged equation of maximum likelihood is depicted as:

$$
\ln L(\theta)=-(1 / 2) \sum_{t=1}^{n}\left[\ln (2 \pi)+\ln \left(\sigma_{t}^{2}(\theta)\right)+z_{t}^{2}(\theta)\right]
$$

where

$\theta$ is the vector of parameters $(\mu, \omega, \alpha, \beta)$ estimated that maximize the objective function $\ln L(\theta)$,

$\mathrm{z}_{\mathrm{t}}$ represents the standardized residual calculated as $\left(\Delta y_{t}-\mu\right) / \sqrt{\sigma_{t}^{2}}$.

\subsection{Diagnostic Checking of the Model ARCH-GARCH}

There are plenty diagnostic tests for the analysis of ARCH- GARCH modeling. The residual correlogram is used to test the residual autocorrelation, while the squared residual correlogram is used to test the autocorrelation of the conditional heteroscedasticity of residuals. To define if the time-series presents autocorrelation or heteroscedasticity we use the Ljung and Box (Q-statistics) (1978). This statistics are depicted as:

$$
Q_{m}=n(n+2) \sum_{k=1}^{m} e_{k}^{2} /(n-2)
$$

where:

$e_{k}$ is the residual autocorrelation in lag $k$.

$n$ is the residual number.

$m$ is the time-lags number tested.

The model is appropriate when the probability of Ljung and Box Q-statistics is higher than 5\%.

\subsection{The GARCH-M Model}

Engle, Lilien, and Robins (1987), build on the ARCH(q) methodology for the purpose of conditional covariance influencing the mean order. In other words we could say that Engle, Lilien, and Robins (1987) restructured the conditional variance model in order that the mean of a sequence to be depended on the conditional covariance. These models are named ARCH-M and are adequately adjusted to the study of the return of financial products. The model that Engle, Lilien and Robins built is the following: 


$$
\begin{gathered}
R_{t}=\mu+\text { other terms }+\delta \sigma_{t-1}^{2}+\varepsilon_{t} \text { (mean equation) } \\
\sigma_{t}^{2}=\omega+\sum_{i=1}^{q} \alpha_{i} \varepsilon_{t-i}^{2}+\sum_{j=1}^{p} \beta_{j} \sigma_{t-j}^{2} \text { (covariance equation) }
\end{gathered}
$$

where:

$\mu$ is the conditional mean of the stock market return in time $t$.

$\sigma^{2}{ }_{t}$ is the conditional covariance that reflects the risk premium.

$\omega$ is a constant term.

$\varepsilon_{t}$ is the error term in time t.

$\mu, \delta, \omega, \alpha_{i}$ and $\beta_{j}$ are parameters for evaluation.

In this study the model GARCH-M (1,1) is used, considering the study of Bollerslev (1986), where he claims that the length of the time lag of the squared error and the conditional variance is enough for the stock market return model.

GARCH-M $(1,1)$ model equation can be depicted as:

$$
\begin{gathered}
R_{t}=\mu+\text { other terms }+\delta \sigma_{t-1}^{2}+\varepsilon_{t} \text { (mean equation) } \\
\sigma_{t}^{2}=\omega+\alpha_{l} \varepsilon_{t-1}^{2}+\beta_{l} \sigma_{t-1}^{2} \text { (covariance equation) }
\end{gathered}
$$

\subsection{Forecasting Performance}

ARCH-GARCH models are used for forecasting the variance return. Forecasting in ARCH-GARCH models is estimated both in-sample, and out-of-sample. The best forecasting price is given from the mean squared error. Furthermore, other indexes that are usually used for forecast return are the Mean Absolute Error (MAE), Root Mean Square Error (RMSE), Mean Absolute Percentage Error (MAPE) and the inequality index of Theil (U-Theil) (1967).

These indexes are depicted as follows:

$$
\begin{aligned}
M S E & =(1 / T) \sum_{t=1}^{T}\left(\widehat{Y}_{t}-Y_{t}\right)^{2} \\
M A E & =(1 / T) \sum_{t=1}^{T}\left|\widehat{Y}_{t}-Y_{t}\right|^{2} \\
R M S E & =\sqrt{(1 / T) \sum_{t=1}^{T}\left(\widehat{Y}_{t}-Y_{t}\right)^{2}} \\
M A P E & =(1 / T) \sum_{t=1}^{T}\left|\left(\widehat{Y}_{t}-Y_{t}\right) / Y_{t}\right|^{2}
\end{aligned}
$$

the inequality index of Theil is given as:

$$
U=\left(\sqrt{(1 / T) \sum_{t=1}^{T}\left(\widehat{Y}_{t}-Y_{t}\right)^{2}}\right) /\left(\sqrt{(1 / T) \sum_{t=1}^{T}\left(\widehat{Y}_{t}\right)^{2}}+\sqrt{(1 / T) \sum_{t=1}^{T}\left(Y_{t}\right)^{2}}\right) \quad 0 \leq U \leq 1
$$

where:

$Y_{t}$ : Actual value of endogenous variable $Y$ at time t.

$\widehat{Y}_{t}$ : Redacted value of endogenous variable $Y$ at time $\mathrm{t}$.

$\mathrm{T}$ : Number of observations in the simulations (of the sample).

If the inequality index of Theil $U=0$, then the actual prices of the time-series, would equal the predicted ones $Y_{t}=$ $\widehat{Y}_{t}$ for all $t$, therefore in this case we can say that there is a "perfect fit" between actual and predicted data. Otherwise if variable $U=1$, there is no right forecast for the studied model. Consequently the individual indexes of Theil are presented, known as inequality proportions, and are depicted as:

- $\quad$ Bias proportion: indicates the systematic differences in actual and forecasted values.

$$
U M=\left((\bar{Y}-\bar{Y})^{2}\right) /\left((1 / T) \sum_{t=1}^{T}\left(\widehat{Y}_{t}-Y_{t}\right)^{2}\right)
$$

where:

$\overline{\hat{Y}}$ and $\bar{Y}$ are the time-series mean of $\widehat{Y}_{\mathrm{t}}$ and $\mathrm{Y}_{\mathrm{t}}$ correspondingly. Bias proportion counts the distance between the mean of the simulated series and the mean of the actual one.

- $\quad$ Variance proportion: indicates unequal variances of actual and forecasted values.

$$
U S=\left(\left(\hat{S}_{\hat{Y}}-S_{Y}\right)^{2}\right) /\left((1 / T) \sum_{t=1}^{T}\left(\widehat{Y}_{t}-Y_{t}\right)^{2}\right)
$$

where: 
$\hat{S}_{Y}$ and $S_{Y}$ are the standard deviations of series $\widehat{Y}_{\mathrm{t}}$ and $\mathrm{Y}_{\mathrm{t}}$ correspondingly. Variance proportion counts the distance between the variance of the simulated series and the variance of the real one.

- Covariance proportion: indicates the correlation between the actual and forecasted values (zero=perfect correlation between actual and forecasted values).

$$
U C=\left(2(1-\rho) \hat{S}_{Y} S_{Y}\right) /\left((1 / T) \sum_{t=1}^{T}\left(\widehat{Y}_{t}-Y_{t}\right)^{2}\right)
$$

where:

$\rho$ is the correlation variable between $\widehat{Y}_{t}$ and $Y_{t}$. Covariance proportion counts the balance of the non-systematic error of simulation.

The forecasting ability of a model is sufficient, when the bias and covariance proportions are low.

The relationship between the above proportions is:

\section{Data and Descriptive Statistics}

$$
U M+U S+U C=1
$$

The data for this study was collected from the websites www.nasdaqomxnordic.com for the OMX Copenhagen 20, OMX Stockholm 30 and OMX Helsinki 25 indexes and from the website www.oslobors.no for the AXLT index of Oslo Børs. The data covers the period from January $3^{\text {rd }} 1983$ to April $7^{\text {th }} 2016$ for the Norwegian Index and contains 8347 observations, the period from October $10^{\text {th }} 1996$ to May $11^{\text {th }} 2016$ for the Danish Index and contains 4893 observations, the period from September $30^{\text {th }} 1986$ to May $11^{\text {th }} 2016$ for the Swedish Index and contains 7434 observations and lastly the period from September $3^{\text {rd }} 2001$ to May $11^{\text {th }} 2016$ for the Finnish Index and contains 3687 observations.

The daily return of stock markets is calculated as:

where,

$$
R_{t}=\ln \left(X_{t} / X_{t-1}\right) * 100=\left(\ln X_{t}-\ln X_{t-1}\right) * 100
$$

$X_{t}$ is the daily closing price of stock market at time $\mathrm{t}$,

$R_{t}$ is the daily return of stock market.

The daily closing prices of the AXLT, OMX Copenhagen 20, OMX Stockholm 30 and OMX Helsinki 25 Indexes and their returns are presented at Figures 1 and 2, correspondingly.

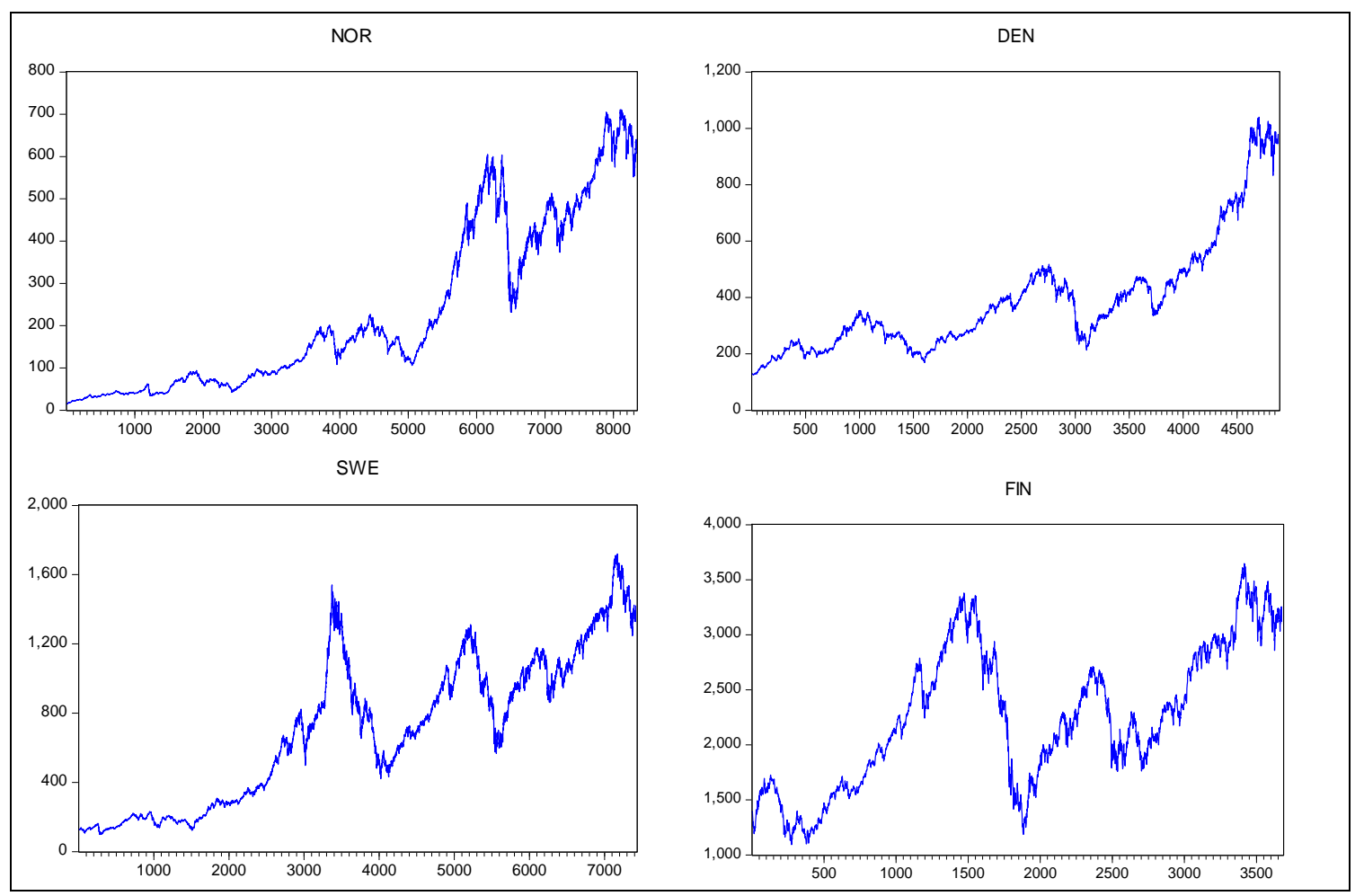

Figure 1. Daily closing prices of the Norwegian, Danish, Swedish and Finnish stock markets 
From Figure 1 we can assume that the daily closing prices of all stock markets display a random walk.

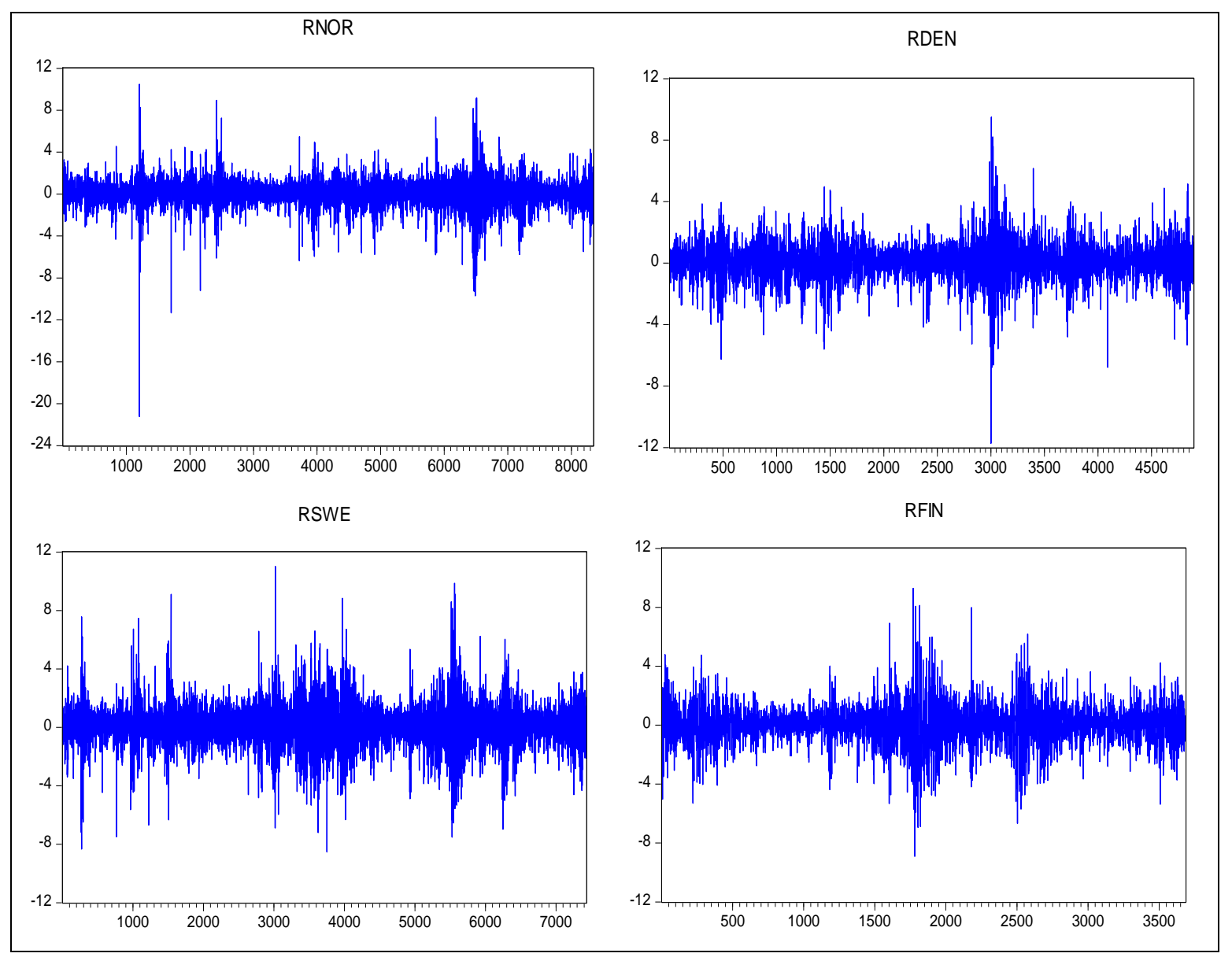

Figure 2. Daily returns of the Norwegian, Danish, Swedish and Finnish stock markets

From Figure 2 we can assume that the daily returns of all the stock markets are stationary. Consequently we can move on to Tables 1 and 2 of correlograms and check if autocorrelation exists in the daily returns of stock markets, as well as the form of autocorrelation in the correlograms of the daily squared returns.

Table 1. Correlogram of the daily return of the Norwegian, Danish, Swedish and Finnish stock markets

\begin{tabular}{|c|c|c|c|c|c|c|c|c|c|c|c|}
\hline \multicolumn{6}{|c|}{$\begin{array}{l}\text { Sample: } 18347 \\
\text { Included observations: } 8346\end{array}$} & \multicolumn{6}{|c|}{$\begin{array}{l}\text { Sample: } 14893 \\
\text { Included observations: } 4892\end{array}$} \\
\hline Autocorrelation & $\begin{array}{l}\text { Partial Correlation } \\
\end{array}$ & $\mathrm{AC}$ & PAC & Q-Stat & Prob & Autocorrelation & Partial Correlation & $\mathrm{AC}$ & PAC & a-stat & Prob \\
\hline & & 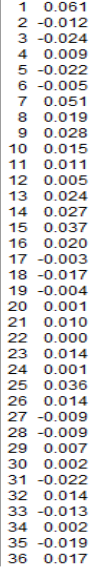 & 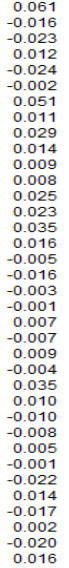 & 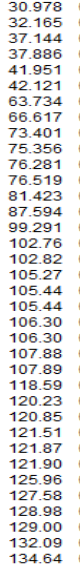 & 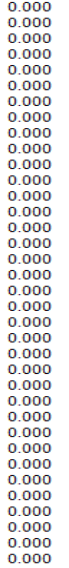 & 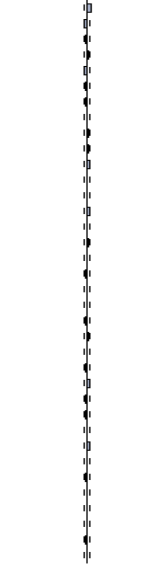 & 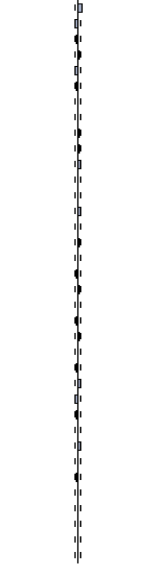 & 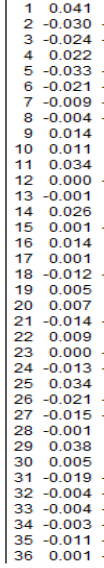 & 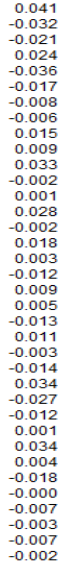 & 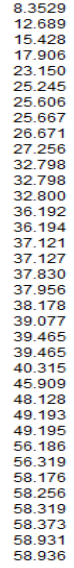 & $\begin{array}{l}0.004 \\
0.002 \\
0.001 \\
0.001 \\
0.000 \\
0.000 \\
0.001 \\
0.001 \\
0.002 \\
0.002 \\
0.001 \\
0.001 \\
0.002 \\
0.001 \\
0.002 \\
0.002 \\
0.003 \\
0.004 \\
0.000 \\
0.008 \\
0.010 \\
0.012 \\
0.018 \\
0.020 \\
0.007 \\
0.005 \\
0.006 \\
0.008 \\
0.002 \\
0.003 \\
0.002 \\
0.003 \\
0.004 \\
0.006 \\
0.007 \\
0.009\end{array}$ \\
\hline
\end{tabular}




\begin{tabular}{|c|c|c|c|c|c|c|c|c|c|c|c|c|c|}
\hline \multicolumn{7}{|c|}{$\begin{array}{l}\text { Sample: } 17432 \\
\text { Included observations: } 7431\end{array}$} & \multicolumn{7}{|c|}{$\begin{array}{l}\text { Sample: } 13687 \\
\text { Included observations: } 3686\end{array}$} \\
\hline Autocorrelation & Partial Correlation & & $\mathrm{AC}$ & PAC & Q-Stat & Prob & Autocorrelation & Partial Correlation & & $A C$ & PAC & Q-Stat & Prob \\
\hline ! & $!$ & \begin{tabular}{|r}
1 \\
2 \\
3 \\
4 \\
5 \\
6 \\
7 \\
8 \\
9 \\
10 \\
11 \\
12 \\
13 \\
14 \\
15 \\
16 \\
17 \\
18 \\
19 \\
20 \\
21 \\
22 \\
23 \\
24 \\
25 \\
26 \\
27 \\
28 \\
29 \\
30 \\
31 \\
32 \\
33 \\
34 \\
35 \\
36
\end{tabular} & $\begin{array}{r}0.022 \\
-0.028 \\
-0.034 \\
0.001 \\
-0.008 \\
-0.035 \\
0.008 \\
0.015 \\
0.019 \\
-0.019 \\
0.015 \\
0.022 \\
0.014 \\
0.011 \\
0.023 \\
0.022 \\
0.013 \\
-0.026 \\
-0.037 \\
-0.001 \\
-0.003 \\
-0.001 \\
0.032 \\
0.021 \\
0.059 \\
0.011 \\
-0.005 \\
0.001 \\
0.024 \\
0.007 \\
-0.022 \\
-0.016 \\
-0.001 \\
-0.011 \\
-0.023 \\
0.028\end{array}$ & $\begin{array}{r}0.022 \\
-0.028 \\
-0.033 \\
0.001 \\
-0.010 \\
-0.036 \\
0.009 \\
0.012 \\
0.017 \\
-0.019 \\
0.017 \\
0.021 \\
0.013 \\
0.014 \\
0.026 \\
0.022 \\
0.015 \\
-0.022 \\
-0.033 \\
0.000 \\
-0.005 \\
-0.002 \\
0.031 \\
0.015 \\
0.057 \\
0.012 \\
-0.001 \\
0.004 \\
0.025 \\
0.008 \\
-0.018 \\
-0.015 \\
-0.001 \\
-0.014 \\
-0.020 \\
0.025\end{array}$ & $\begin{array}{l}3.6006 \\
9.2403 \\
17.700 \\
17.702 \\
18.156 \\
27.373 \\
27.826 \\
29.462 \\
32.156 \\
34.838 \\
36.479 \\
40.223 \\
41.606 \\
42.582 \\
46.588 \\
50.319 \\
51.497 \\
56.644 \\
66.698 \\
66.700 \\
66.764 \\
66.768 \\
74.418 \\
77.665 \\
103.30 \\
104.20 \\
104.42 \\
104.42 \\
108.81 \\
109.17 \\
112.93 \\
114.82 \\
114.83 \\
115.80 \\
119.78 \\
125.43\end{array}$ & $\begin{array}{l}0.058 \\
0.010 \\
0.001 \\
0.001 \\
0.003 \\
0.000 \\
0.000 \\
0.000 \\
0.000 \\
0.000 \\
0.000 \\
0.000 \\
0.000 \\
0.000 \\
0.000 \\
0.000 \\
0.000 \\
0.000 \\
0.000 \\
0.000 \\
0.000 \\
0.000 \\
0.000 \\
0.000 \\
0.000 \\
0.000 \\
0.000 \\
0.000 \\
0.000 \\
0.000 \\
0.000 \\
0.000 \\
0.000 \\
0.000 \\
0.000 \\
0.000\end{array}$ & 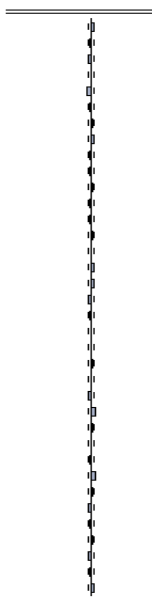 & 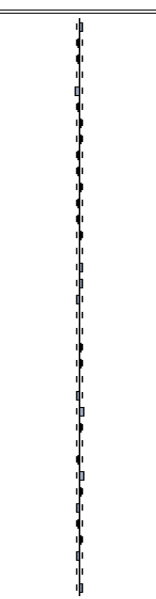 & \begin{tabular}{|r}
1 \\
2 \\
3 \\
4 \\
5 \\
6 \\
7 \\
8 \\
8 \\
9 \\
10 \\
11 \\
12 \\
13 \\
14 \\
15 \\
16 \\
17 \\
18 \\
19 \\
20 \\
21 \\
22 \\
23 \\
24 \\
25 \\
26 \\
27 \\
28 \\
29 \\
30 \\
31 \\
32 \\
33 \\
34 \\
35 \\
36
\end{tabular} & $\begin{array}{r}0.031 \\
-0.012 \\
-0.025 \\
0.000 \\
-0.062 \\
-0.021 \\
0.013 \\
0.025 \\
-0.020 \\
-0.021 \\
0.017 \\
-0.009 \\
-0.012 \\
0.015 \\
0.007 \\
0.038 \\
0.033 \\
-0.043 \\
-0.011 \\
0.003 \\
0.008 \\
0.018 \\
0.001 \\
-0.030 \\
0.053 \\
0.019 \\
-0.004 \\
-0.011 \\
0.049 \\
0.018 \\
-0.039 \\
-0.015 \\
0.023 \\
-0.043 \\
-0.020 \\
0.038\end{array}$ & $\begin{array}{r}0.031 \\
-0.013 \\
-0.024 \\
0.002 \\
-0.062 \\
-0.017 \\
0.013 \\
0.021 \\
-0.022 \\
-0.023 \\
0.016 \\
-0.010 \\
-0.009 \\
0.014 \\
0.001 \\
0.039 \\
0.033 \\
-0.046 \\
-0.005 \\
0.006 \\
0.011 \\
0.021 \\
-0.005 \\
-0.033 \\
0.057 \\
0.022 \\
-0.005 \\
-0.010 \\
0.049 \\
0.019 \\
-0.036 \\
-0.010 \\
0.016 \\
-0.038 \\
-0.005 \\
0.031\end{array}$ & $\begin{array}{l}3.4375 \\
3.9425 \\
6.2420 \\
66.2422 \\
20.220 \\
21.785 \\
22.414 \\
24.684 \\
26.122 \\
27.823 \\
228.847 \\
299.122 \\
29.698 \\
30.495 \\
30.668 \\
355.947 \\
39.957 \\
46.777 \\
47.188 \\
47.220 \\
47.454 \\
48.646 \\
48.651 \\
51.947 \\
62.244 \\
63.629 \\
63.701 \\
64.136 \\
72.905 \\
74.093 \\
79.654 \\
80.459 \\
82.432 \\
89.171 \\
90.611 \\
96.008\end{array}$ & $\begin{array}{l}0.064 \\
0.139 \\
0.100 \\
0.182 \\
0.001 \\
0.001 \\
0.002 \\
0.002 \\
0.002 \\
0.002 \\
0.002 \\
0.004 \\
0.005 \\
0.007 \\
0.010 \\
0.003 \\
0.001 \\
0.000 \\
0.000 \\
0.001 \\
0.001 \\
0.001 \\
0.001 \\
0.001 \\
0.000 \\
0.000 \\
0.000 \\
0.000 \\
0.000 \\
0.000 \\
0.000 \\
0.000 \\
0.000 \\
0.000 \\
0.000 \\
0.000\end{array}$ \\
\hline
\end{tabular}

Ljung and Box (Q-statistics) indicate that a serial correlation exists for all time lags of the autocorrelation function.

Table 2. Correlogram of the squared daily return of the Norwegian, Danish, Swedish and Finnish stock markets.

\begin{tabular}{|c|c|c|c|c|c|c|c|c|c|c|c|c|c|}
\hline \multicolumn{7}{|c|}{$\begin{array}{l}\text { Sample: } 18347 \\
\text { Included observations: } 8346\end{array}$} & \multicolumn{7}{|c|}{$\begin{array}{l}\text { Sample: } 14893 \\
\text { Included observations: } 4892\end{array}$} \\
\hline Autocorrelation & Partial Correlation & & $A C$ & PAC & Q-Stat & Prob & Autocorrelation & Partial Correlation & & $\mathrm{AC}$ & PAC & Q-Stat & Prob \\
\hline 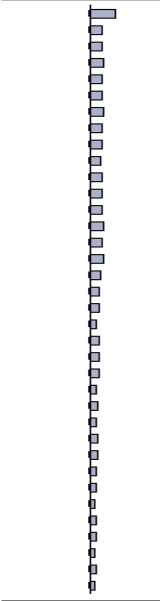 & 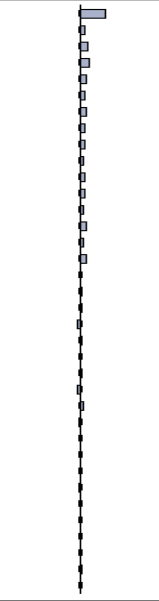 & $\begin{array}{l}28 \\
29 \\
30 \\
31 \\
32 \\
33 \\
34 \\
35 \\
36 \\
3\end{array}$ & $\begin{array}{l}0.307 \\
0.148 \\
0.143 \\
0.162 \\
0.153 \\
0.137 \\
0.157 \\
0.150 \\
0.150 \\
0.120 \\
0.120 \\
0.134 \\
0.154 \\
0.137 \\
0.167 \\
0.147 \\
0.168 \\
0.127 \\
0.112 \\
0.111 \\
0.073 \\
0.104 \\
0.100 \\
0.109 \\
0.069 \\
0.096 \\
0.079 \\
0.082 \\
0.088 \\
0.078 \\
0.072 \\
0.065 \\
0.068 \\
0.065 \\
0.074 \\
0.055\end{array}$ & 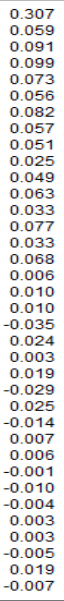 & 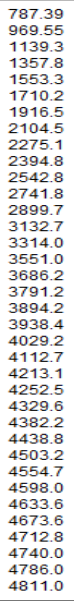 & $\begin{array}{l}0.000 \\
0.000 \\
0.000 \\
0.000 \\
0.000 \\
0.000 \\
0.000 \\
0.0000 \\
0.0000 \\
0.000 \\
0.000 \\
0.000 \\
0.0000 \\
0.000 \\
0.000 \\
0.000 \\
0.000 \\
0.0000 \\
0.000 \\
0.000 \\
0.000 \\
0.000 \\
0.000 \\
0.000 \\
0.000 \\
0.000 \\
0.000 \\
0.000 \\
0.000 \\
0.000 \\
0.000 \\
0.000 \\
0.000 \\
0.000 \\
0.000 \\
0.000\end{array}$ & $\begin{array}{c}\text { 官 } \\
\text { 官 } \\
\text { 官 } \\
\text { 官 } \\
\text { 官 } \\
\text { 官 } \\
\text { ":官 } \\
\text { 官 } \\
\text { 官 } \\
\text { 官 } \\
\text { 官 } \\
\text { 官 } \\
\text { 官 } \\
\text { 官 }\end{array}$ & 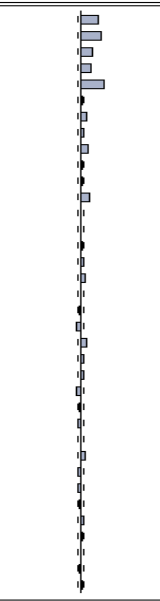 & & $\begin{array}{l}0.216 \\
0.291 \\
0.224 \\
0.237 \\
0.375 \\
0.181 \\
0.252 \\
0.187 \\
0.248 \\
0.214 \\
0.184 \\
0.262 \\
0.161 \\
0.197 \\
0.170 \\
0.193 \\
0.222 \\
0.155 \\
0.159 \\
0.100 \\
0.217 \\
0.169 \\
0.168 \\
0.096 \\
0.099 \\
0.128 \\
0.113 \\
0.157 \\
0.068 \\
0.085 \\
0.077 \\
0.110 \\
0.122 \\
0.076 \\
0.075 \\
0.075\end{array}$ & 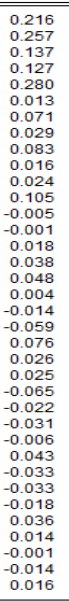 & 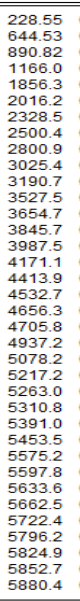 & $\begin{array}{l}0.00 \\
0.000 \\
0.000 \\
0.000 \\
0.000 \\
0.000 \\
0.000 \\
0.000 \\
0.000 \\
0.000 \\
0.0000 \\
0.0000 \\
0.000 \\
0.000 \\
0.000 \\
0.000 \\
0.000 \\
0.000 \\
0.000 \\
0.000 \\
0.000 \\
0.000 \\
0.000 \\
0.000 \\
0.000 \\
0.000 \\
0.000 \\
0.000 \\
0.000 \\
0.000 \\
0.000 \\
0.000 \\
0.000 \\
0.000 \\
0.000 \\
0.000 \\
0.000\end{array}$ \\
\hline \multicolumn{7}{|c|}{$\begin{array}{l}\text { Sample: } 17432 \\
\text { Included observations: } 7431 \\
\end{array}$} & \multicolumn{7}{|c|}{$\begin{array}{l}\text { Sample: } 13687 \\
\text { Included observations: } 3686\end{array}$} \\
\hline $\begin{array}{l}\text { Autocorrelation } \\
\end{array}$ & $\begin{array}{l}\text { Partial Correlation } \\
\end{array}$ & & $\mathrm{AC}$ & PAC & Q-Stat & Prob & Autocorrelation & Partial Correlation & & AC & PAC & Q-Stat & Prob \\
\hline $\begin{array}{l}\text { 官 } \\
\text { 官 } \\
\text { 官 } \\
\text { 官 } \\
\text { 官 } \\
\text { 官 } \\
\text { 官 } \\
\text { 官 } \\
\text { 官 } \\
\text { 官 } \\
\text { 官 } \\
\text { 官 }\end{array}$ & 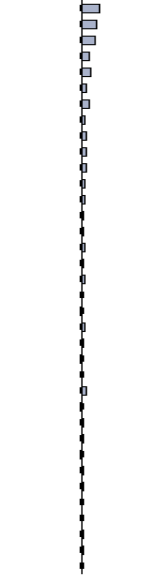 & 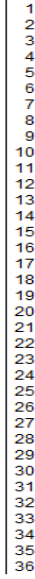 & $\begin{array}{l}0.218 \\
0.217 \\
0.234 \\
0.185 \\
0.210 \\
0.174 \\
0.192 \\
0.159 \\
0.175 \\
0.184 \\
0.179 \\
0.158 \\
0.161 \\
0.143 \\
0.145 \\
0.152 \\
0.135 \\
0.152 \\
0.126 \\
0.105 \\
0.147 \\
0.132 \\
0.106 \\
0.114 \\
0.144 \\
0.096 \\
0.114 \\
0.123 \\
0.082 \\
0.114 \\
0.116 \\
0.098 \\
0.100 \\
0.103 \\
0.112 \\
0.094\end{array}$ & 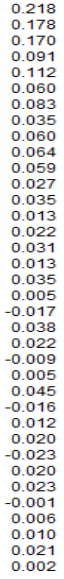 & 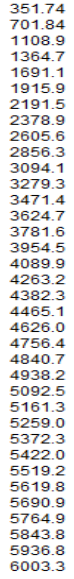 & $\begin{array}{l}0.000 \\
0.000 \\
0.000 \\
0.000 \\
0.000 \\
0.000 \\
0.000 \\
0.000 \\
0.000 \\
0.000 \\
0.000 \\
0.000 \\
0.000 \\
0.000 \\
0.000 \\
0.000 \\
0.000 \\
0.000 \\
0.000 \\
0.000 \\
0.000 \\
0.000 \\
0.000 \\
0.000 \\
0.000 \\
0.000 \\
0.000 \\
0.000 \\
0.000 \\
0.000 \\
0.000 \\
0.000 \\
0.000 \\
0.000 \\
0.000 \\
0.000 \\
0.000\end{array}$ & $\begin{array}{c}\text { 官 } \\
\text { 官 } \\
\text { 官官 } \\
\text { 官 } \\
\text { 官 } \\
\text { 官 } \\
\text { 官 } \\
\text { 官 } \\
\text { 官 } \\
\text { 官 } \\
\text { 官 } \\
\text { 官 }\end{array}$ & 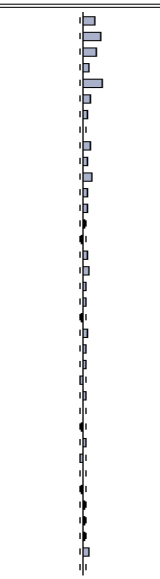 & & 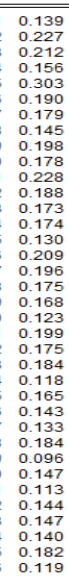 & $\begin{array}{l}0.139 \\
0.212 \\
0.2168 \\
0.080 \\
0.229 \\
0.097 \\
0.049 \\
0.005 \\
0.087 \\
0.042 \\
0.106 \\
0.061 \\
0.047 \\
0.023 \\
-0.017 \\
0.059 \\
0.068 \\
0.037 \\
0.025 \\
-0.018 \\
0.018 \\
0.027 \\
0.038 \\
-0.035 \\
-0.036 \\
-0.000 \\
-0.017 \\
0.033 \\
-0.030 \\
-0.000 \\
-0.012 \\
0.021 \\
0.014 \\
0.020 \\
0.066 \\
0.007\end{array}$ & 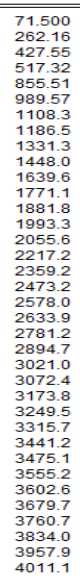 & 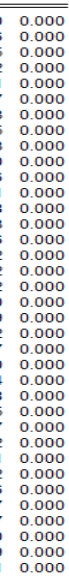 \\
\hline
\end{tabular}


Results of Table 2 indicate that Ljung and Box (Q-statistics) for all time lags is statistical significant, therefore an ARCH effect exists.

Table 3. Descriptive statistics of the daily return of the Norwegian, Danish, Swedish and Finnish stock markets

\begin{tabular}{ccccc}
\hline & NOR & DEN & SWE & FIN \\
\hline Mean & 0.045110 & 0.041417 & 0.031782 & 0.021683 \\
Median & 0.092587 & 0.085747 & 0.069711 & 0.063065 \\
Maximum & 10.48099 & 9.496355 & 11.02284 & 9.285563 \\
Minimum & -21.21879 & -11.72319 & -8.526937 & -8.905445 \\
Std. Dev. & 1.320211 & 1.289933 & 1.462234 & 1.444397 \\
Skewness & -1.012962 & -0.268218 & 0.025068 & -0.036580 \\
Kurtosis & 17.89832 & 7.847888 & 7.250442 & 6.317618 \\
Jarque-Bera & 78613.88 & 4849.151 & 5594.544 & 1691.251 \\
Probability & 0.000000 & 0.000000 & 0.000000 & 0.000000 \\
Sum & 376.4856 & 202.6100 & 236.1706 & 79.92401 \\
Sum Sq.Dev. & 14544.98 & 8138.264 & 15886.28 & 7687.956 \\
Observations & 8346 & 4892 & 7431 & 3686 \\
\hline
\end{tabular}

Table 4. Stationarity test of the daily return of the Norwegian, Danish, Swedish and Finnish stock markets

\begin{tabular}{lcccc}
\hline \multirow{2}{*}{ Variable } & \multicolumn{2}{c}{ ADF } & \multicolumn{2}{c}{ P-P } \\
\cline { 2 - 5 } & C & C,T & C & C,T \\
\hline RNOR & $-85.93(0)^{*}$ & $-85.95(0)^{*}$ & $-86.51[25]^{*}$ & $-86.50[25]^{*}$ \\
R SWE & $-84.31(0)^{*}$ & $-84.31(0)^{*}$ & $-84.32[15]^{*}$ & $-84.32[15]^{*}$ \\
RFIN & $-58.86(0)^{*}$ & $-58.85(0)^{*}$ & $-58.87[11]^{*}$ & $-58.86[11]^{*}$ \\
RDEN & $-67.09(0)^{*}$ & $-67.08(0)^{*}$ & $-67.03[14]^{*}$ & $-67.02[14]^{*}$ \\
\hline
\end{tabular}

Note. 1. *,** and *** show significant at $1 \%, 5 \%$ and $10 \%$ levels respectively.

2. The numbers within parentheses followed by ADF statistics represent the lag length of the dependent variable used to obtain white noise residuals.

3. The lag lengths for ADF equation were selected using Schwarz Information Criterion (SIC).

4. Mackinnon (1996) critical value for rejection of hypothesis of unit root applied.

5. The numbers within brackets followed by PP statistics represent the bandwidth selected based on Newey West (1994) method using Bartlett Kernel.

6. $\mathrm{C}=$ Constant, $\mathrm{T}=$ Trend..

After the stationarity detection with tests Dickey-Fuller (1979, 1981) and Phillips-Perron (1988) of all time-series we can define the form of model ARMA $(p, q)$ from the correlogram of Table 1. Parameters $p$ and $q$ can be defined from the partial autocorrelation and correlation variable, correspondingly, comparing them with the critical value $\pm 2 / \sqrt{n}= \pm 2 / \sqrt{8347}= \pm 0.022$ for the Norwegian stock exchange, \pm 0.028 for the Danish stock exchange, \pm 0.023 for the Swedish stock exchange and \pm 0.032 for the Finnish stock exchange.

Therefore for Norway and Finland $p$ value will be $0<p<1$ and $q$ value will be $0<q<1$, for Denmark $p$ value will be $0<p<2$ and $q$ value will be $0<q<2$ and lastly for Sweden $p$ value will be $0<p<3$ and $q$ value will be $0<q<3$.

Consequently we can create Table 5 as such:

Table 5. Comparison of models within the range of exploration using AIC, SIC and HQ

\begin{tabular}{ccccc}
\hline \multicolumn{2}{c}{ ARIMA model } & AIC & SC & HQ \\
\hline RNOR & & & & \\
& $(1,0,0)$ & 3.3903 & 3.3928 & 3.3912 \\
& $(\mathbf{0 , 0 , 1 )}$ & $\mathbf{3 . 3 9 0 2}$ & $\mathbf{3 . 3 9 2 7}$ & $\mathbf{3 . 3 9 1 1}$ \\
$(1,0,1)$ & 3.3904 & 3.3938 & 3.3915 \\
\hline $\mathbf{R}$ DEN & & & \\
\hline & $\mathbf{( 0 , 0 , 1 )}$ & $\mathbf{3 . 3 4 6 2}$ & $\mathbf{3 . 3 5 0 2}$ & $\mathbf{3 . 3 4 7 6}$ \\
$(0,0,2)$ & 3.3469 & 3.3512 & 3.3478 \\
$(1,0,0)$ & 3.3463 & 3.3503 & 3.3477 \\
$(1,0,1)$ & 3.3463 & 3.3516 & 3.3482 \\
$(1,0,2)$ & 3.3468 & 3.3524 & 3.3481 \\
$(2,0,0)$ & 3.3462 & 3.3510 & 3.3476 \\
$(2,0,1)$ & 3.3463 & 3.3524 & 3.3481 \\
$(2,0,2)$ & 3.3462 & 3.3532 & 3.3480 \\
\hline
\end{tabular}




\begin{tabular}{ccccc}
\hline R SWE & & & & \\
& $(0,0,1)$ & 3.5979 & 3.6017 & 3.5989 \\
& $(0,0,2)$ & 3.5975 & 3.6012 & 3.5988 \\
& $(\mathbf{0 , 0 , 3})$ & $\mathbf{3 . 5 9 6 5}$ & $\mathbf{3 . 6 0 1 2}$ & $\mathbf{3 . 5 9 8 1}$ \\
$(1,0,0)$ & 3.5979 & 3.6017 & 3.5989 \\
$(1,0,1)$ & 3.5980 & 3.6017 & 3.5993 \\
$(1,0,2)$ & 3.5968 & 3.6015 & 3.5984 \\
$(1,0,3)$ & 3.5968 & 3.6024 & 3.5987 \\
& $(2,0,0)$ & 3.5974 & 3.6012 & 3.5987 \\
& $(2,0,1)$ & 3.5968 & 3.6014 & 3.5983 \\
& $(2,0,2)$ & 3.5969 & 3.6025 & 3.5989 \\
& $(2,0,3)$ & 3.5970 & 3.6035 & 3.5993 \\
& $(3,0,0)$ & 3.5966 & 3.6013 & 3.5982 \\
& $(3,0,1)$ & 3.5969 & 3.6025 & 3.5988 \\
& $(3,0,2)$ & 3.5971 & 3.6036 & 3.5993 \\
$\mathbf{R}$ & 3.5965 & 3.6039 & 3.5990 \\
\hline $\mathbf{R}$ FIN & & & & 3.57548 \\
& $(1,0,3)$ & 3.57368 & 3.57874 & $\mathbf{3 . 5 7 5 4 6}$ \\
& $(\mathbf{0 , 0 , 1 )}$ & $\mathbf{3 . 5 7 3 6 6}$ & $\mathbf{3 . 5 7 8 7 2}$ & 3.5765 \\
\hline
\end{tabular}

The results from Table 5 indicate that according to the criteria of Akaike (AIC), Schwartz (SIC) and Hannan-Quinn (HQ) model ARIMA $(0,0,1)$ is the fittest for the Norwegian, Finnish and Danish stock while model ARIMA $(0,0,3)$ for the Swedish one.

Table 6. ARMA models estimation

\begin{tabular}{|c|c|c|c|c|}
\hline \multicolumn{5}{|c|}{$\begin{array}{l}\text { Dependent Variable: RNOR } \\
\text { Method: ARMA Maximum Likelihood (OPG - BHHH) } \\
\text { Date: } 09 / 08 / 16 \text { Time: } 10: 04 \\
\text { Sample: } 28347 \\
\text { Included observations: } 8346 \\
\text { Convergence achieved after } 65 \text { iterations } \\
\text { Coefficient covariance computed using outer product of gradients }\end{array}$} \\
\hline Variable & Coefficient & Std. Error & t-Statistic & Prob. \\
\hline $\begin{array}{c}\text { C } \\
\text { MA(1) } \\
\text { SIGMASQ }\end{array}$ & $\begin{array}{l}0.045099 \\
0.062339 \\
1.736120\end{array}$ & $\begin{array}{l}0.016066 \\
0.004407 \\
0.009588\end{array}$ & $\begin{array}{l}2.807182 \\
14.14640 \\
181.0735\end{array}$ & $\begin{array}{l}0.0050 \\
0.0000 \\
0.0000\end{array}$ \\
\hline $\begin{array}{l}\text { R-squared } \\
\text { Adjusted R-squared } \\
\text { S.E. of regression } \\
\text { Sum squared resid } \\
\text { Log likelihood } \\
\text { F-statistic } \\
\text { Prob(F-statistic) }\end{array}$ & $\begin{array}{r}0.003804 \\
0.003565 \\
1.317856 \\
14489.65 \\
-14144.51 \\
15.92906 \\
0.000000\end{array}$ & $\begin{array}{l}\text { Mean depen } \\
\text { S.D. depende } \\
\text { Akaike info } \mathrm{cr} \\
\text { Schwarz crite } \\
\text { Hannan-Quir } \\
\text { Durbin-Wats }\end{array}$ & $\begin{array}{l}\text { int var } \\
\text { it var } \\
\text { erion } \\
\text { on } \\
\text { criter. } \\
\text { istat }\end{array}$ & $\begin{array}{l}0.045110 \\
1.320211 \\
3.390249 \\
3.392776 \\
3.391112 \\
2.001003\end{array}$ \\
\hline Inverted MA Roots & -.06 & & & \\
\hline
\end{tabular}

Dependent Variable: RSWE

Method: ARMA Maximum Likelihood (OPG - BHHH)

Date: 09/28/16 Time: 13:31

Sample: 27432

Included observations: 7431

Convergence achieved after 23 iterations

Coefficient covariance computed using outer product of gradients

\begin{tabular}{lrrrr}
\hline \multicolumn{1}{c}{ Variable } & Coefficient & Std. Error & t-Statistic & Prob. \\
\hline \hline \multicolumn{1}{c}{ C } & 0.031768 & 0.016839 & 1.886558 & 0.0593 \\
MA(1) & 0.021677 & 0.007570 & 2.863561 & 0.0042 \\
MA(2) & -0.027264 & 0.007630 & -3.573291 & 0.0004 \\
MA(3) & -0.036572 & 0.007491 & -4.882066 & 0.0000 \\
SIGMASQ & 2.132627 & 0.020084 & 106.1845 & 0.0000 \\
\hline \hline R-squared & 0.002438 & Mean dependent var & 0.031782 \\
Adjusted R-squared & 0.001901 & S.D. dependent var & 1.462234 \\
S.E. of regression & 1.460843 & Akaike info criterion & 3.596578 \\
Sum squared resid & 15847.55 & Schwarz criterion & 3.601230 \\
Log likelihood & -13358.09 & Hannan-Quinn criter. & 3.598176 \\
F-statistic & 4.537761 & Durbin-Watson stat & 1.999909 \\
Prob(F-statistic) & 0.001163 & & & \\
\hline \hline Inverted MA Roots & .35 & $-.19+.26 i$ & $-.19-.26 i$ & \\
\hline \hline
\end{tabular}

Dependent Variable: RDEN

Method: ARMA Maximum Likelihood (OPG - BHHH)

Date: 09/20/16 Time: 13:27

Sample: 24893

Included observations: 4892

Convergence achieved after 19 iterations

Coefficient covariance computed using outer product of gradients

\begin{tabular}{lclcc}
\hline \hline \multicolumn{1}{c}{ Variable } & Coefficient & Std. Error & t-Statistic & Prob. \\
\hline \hline MA(1) & 0.041419 & 0.019522 & 2.121716 & 0.0339 \\
SIGMASQ & 0.043848 & 0.009314 & 4.707982 & 0.0000 \\
& 1.660569 & 0.018323 & 90.62963 & 0.0000 \\
\hline \hline R-squared & 0.001814 & Mean dependent var & 0.041417 \\
Adjusted R-squared & 0.001406 & S.D. dependent var & 1.289933 \\
S.E. of regression & 1.289026 & Akaike info criterion & 3.346264 \\
Sum squared resid & 8123.502 & Schwarz criterion & 3.350247 \\
Log likelihood & -8181.962 & Hannan-Quinn criter. & 3.347662 \\
F-statistic & 4.442121 & Durbin-Watson stat & 2.002324 \\
Prob(F-statistic) & 0.011818 & & & \\
\hline \hline Inverted MA Roots & -.04 & & & \\
\hline \hline
\end{tabular}

Dependent Variable: RFIN

Method: ARMA Maximum Likelihood (OPG - BHHH)

Date: 09/20/16 Time: 13.29

Sample: 23687

Included observations: 368

Convergence achieved after 15 iterations

Coefficient covariance computed using outer product of gradients

\begin{tabular}{lclll}
\hline \hline \multicolumn{1}{c}{ Variable } & Coefficient & Std. Error & t-Statistic & Prob. \\
\hline \hline MA(1) & 0.021689 & 0.024894 & 0.871258 & 0.3837 \\
\multicolumn{1}{c}{ SIGMASQ } & 0.031205 & 0.012778 & 2.442078 & 0.0146 \\
& 2.083729 & 0.029878 & 69.74029 & 0.0000 \\
\hline \hline R-squared & 0.000954 & Mean dependent var & 0.021683 \\
Adjusted R-squared & 0.000411 & S.D. dependent var & 1.444397 \\
S.E. of regression & 1.444100 & Akaike info criterion & 3.573664 \\
Sum squared resid & 7680.624 & Schwarz criterion & 3.578720 \\
Log likelihood & -6583.263 & Hannan-Quinn criter. & 3.575464 \\
F-statistic & 1.757709 & Durbin-Watson stat & 2.000585 \\
Prob(F-statistic) & 0.172584 & & & \\
\hline \hline Inverted MA Roots & -.03 & & \\
\hline \hline
\end{tabular}


After the model estimation we test the existence of conditional heteroscedasticity (ARCH(q) test), from the squared residuals of the last model. Table 7 presents us with the results.

Table 7. ARCH(q) effect test

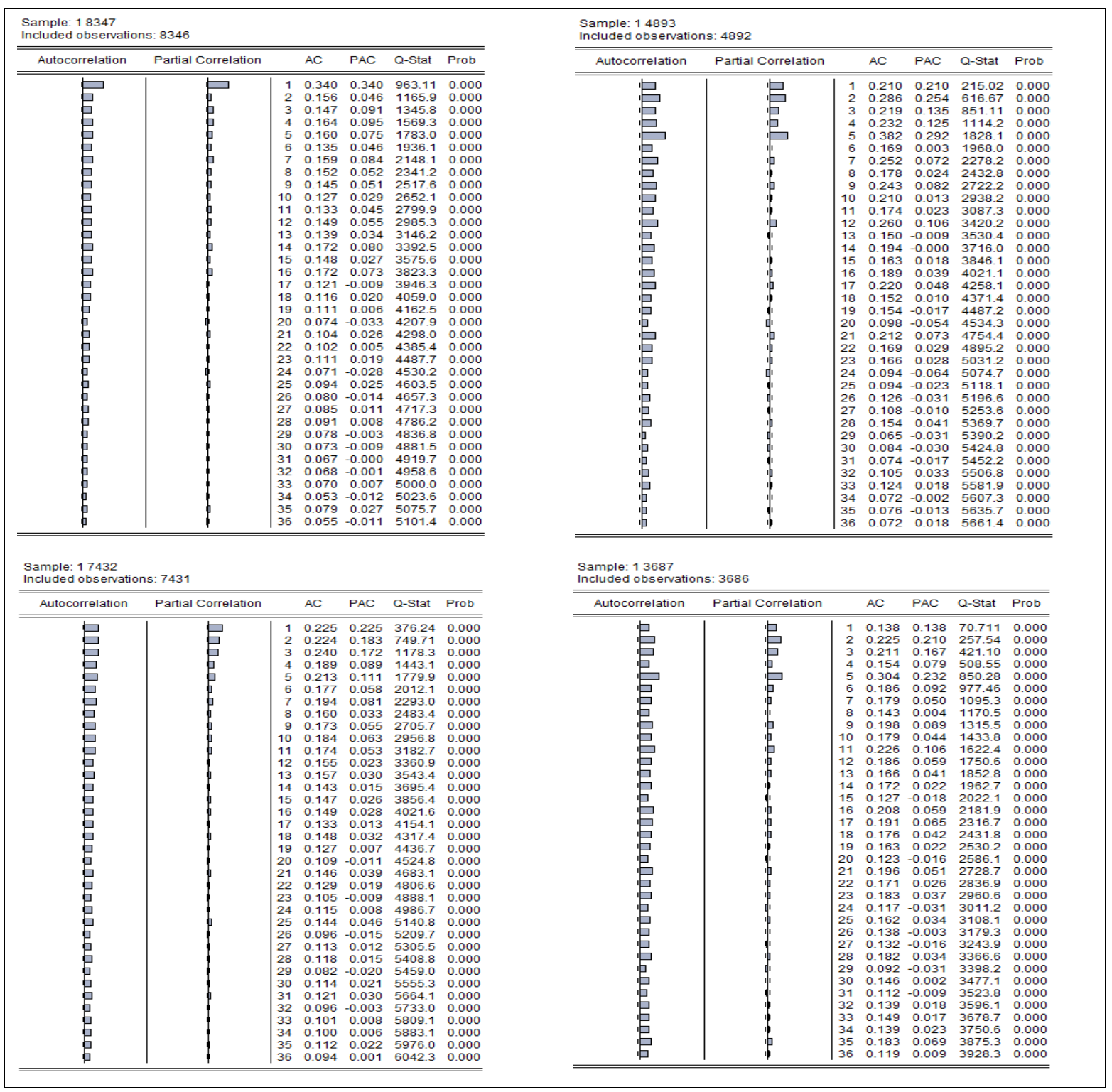

Table 7 results indicate that the autocorrelation and partial autocorrelation variables are statistically significant. Therefore the null hypothesis for the absence of ARCH or GARCH effect is rejected.

\section{Empirical Results}

Keeping in mind that the ARCH effect exists in the returns of the stock markets of Norway, Denmark, Sweden and Finland we can move on to the evaluation of the models ARCH(q), GARCH(p, q) and GARCH-M(p, q). The parameters are evaluated with the BHHH algorithm (Berndt et al., 1974). The evaluation of models ARCH-GARCH-GARCH-M is presented in Tables $8 \mathrm{a}, 8 \mathrm{~b}, 8 \mathrm{c}$ and $8 \mathrm{~d}$ using three distributions for every country. 
Table 8a. Estimated ARCH-GARCH-GARCH-M models for the daily returns of Norway

\begin{tabular}{|c|c|c|c|}
\hline \multicolumn{4}{|c|}{ ARMA(0,1)-ARCH $(1,0)$} \\
\hline Parameter & Normal & t-Student & GED \\
\hline$\omega$ & $1.049(0.000)$ & $1.058(0.000)$ & $1.018(0.000)$ \\
\hline \multirow{2}{*}{$\alpha_{1}$} & $0.401(0.000)$ & $0.408(0.000)$ & $0.387(0.000)$ \\
\hline & & D.O.F $=4.226(0.000)$ & $\mathrm{PAR}=1.142(0.000)$ \\
\hline LL & -13400.04 & -12834.64 & -12896.37 \\
\hline Jarque-Bera & $11940.87(0.000)$ & $13041.28(0.000)$ & $13068.85(0.000)$ \\
\hline $\mathrm{ARCH}(1)$ & $1.364(0.242)$ & $1.753(0.1855)$ & $1.616(0.204)$ \\
\hline$Q^{2}(1)$ & $1.365(0.243)$ & $1.754(0.185)$ & $1.615(0.2037)$ \\
\hline \multicolumn{4}{|c|}{ ARMA(0,1)-GARCH(1,1) } \\
\hline Parameter & Normal & t-Student & GED \\
\hline$\omega$ & $0.056(0.000)$ & $0.036(0.000)$ & $0.043(0.000)$ \\
\hline$\alpha_{1}$ & $0.162(0.000)$ & $0.126(0.000)$ & $0.138(0.000)$ \\
\hline \multirow[t]{2}{*}{$\beta_{1}$} & $0.808(0.000)$ & $0.852(0.000)$ & $0.837(0.000)$ \\
\hline & & D.O.F $=7.686(0.000)$ & $\mathrm{PAR}=1.405(0.000)$ \\
\hline LL & -12591.19 & -12360.71 & -12410.64 \\
\hline Jarque-Bera & $10895.61(0.000)$ & $1428.65(0.000)$ & $12761.06(0.000)$ \\
\hline $\mathrm{ARCH}(30)$ & $23.758(0.783)$ & $30.736(0.428)$ & $27.712(0.586)$ \\
\hline $\mathrm{Q}^{2}(30)$ & $23.390(0.799)$ & $30.490(0.441)$ & $28.059(0.567)$ \\
\hline \multicolumn{4}{|c|}{ ARMA $(0,1)-G A R C H-M(1,1)$} \\
\hline Parameter & Normal & t-Student & GED \\
\hline$\omega$ & $0.056(0.000)$ & $0.036(0.000)$ & $0.043(0.000)$ \\
\hline$\alpha_{1}$ & $0.162(0.000)$ & $0.126(0.000)$ & $0.138(0.000)$ \\
\hline \multirow[t]{2}{*}{$\beta_{1}$} & $0.809(0.000)$ & $0.852(0.000)$ & $0.837(0.000)$ \\
\hline & & D.O.F $=7.686(0.000)$ & $\mathrm{PAR}=1.405(0.000)$ \\
\hline LL & -12591.18 & -12360.70 & -12410.60 \\
\hline Jarque-Bera & 10899.43 & $14212.21(0.000)$ & $12742.25(0.000)$ \\
\hline $\mathrm{ARCH}(30)$ & $23.821(0.780)$ & $30.697(0.430)$ & $27.914(0.575)$ \\
\hline$Q^{2}(30)$ & $23.453(0.796)$ & $30.449(0.0443)$ & $27.564(0.594)$ \\
\hline
\end{tabular}

Note. 1.Values in parentheses denote the $p$-values. 2. LL is the value of the log-likelihood.

Table 8b. Estimated ARCH-GARCH-GARCH-M models for the daily returns of Denmark

\begin{tabular}{|c|c|c|c|}
\hline \multicolumn{4}{|c|}{ ARMA(0,1)-ARCH $(1,0)$} \\
\hline Parameter & Normal & t-Student & GED \\
\hline$\omega$ & $1.154(0.000)$ & $1.179(0.000)$ & $1.138(0.000)$ \\
\hline \multirow[t]{2}{*}{$\alpha_{1}$} & $0.315(0.000)$ & $0.319(0.000)$ & $0.311(0.000)$ \\
\hline & & D.O.F $=4.888(0.000)$ & $\mathrm{PAR}=1.243(0.000)$ \\
\hline LL & -7952.25 & -7757.382 & -7771.147 \\
\hline Jarque-Bera & $1703.559(0.000)$ & $1723.106(0.000)$ & $1719.885(0.000)$ \\
\hline $\mathrm{ARCH}(1)$ & $5.540(0.018)$ & $5.242(0.022)$ & $5.437(0.019)$ \\
\hline $\mathrm{Q}^{2}(1)$ & $5.544(0.019)$ & $5.246(0.022)$ & $5.441(0.020)$ \\
\hline \multicolumn{4}{|c|}{ ARMA $(0,1)-G A R C H(1,1)$} \\
\hline Parameter & Normal & t-Student & GED \\
\hline$\omega$ & $0.050(0.000)$ & $0.044(0.000)$ & $0.047(0.000)$ \\
\hline$\alpha_{1}$ & $0.111(0.000)$ & $0.117(0.000)$ & $0.115(0.000)$ \\
\hline \multirow[t]{2}{*}{$\beta_{1}$} & $0.856(0.000)$ & $0.856(0.000)$ & $0.855(0.000)$ \\
\hline & & D.O.F $=9.752(0.000)$ & $\mathrm{PAR}=1.523(0.000)$ \\
\hline LL & -7557.238 & -7499.126 & -7507.439 \\
\hline Jarque-Bera & $556.6304(0.000)$ & $611.3892(0.000)$ & $584.5145(0.000)$ \\
\hline $\mathrm{ARCH}(30)$ & $24.802(0.734)$ & $26.952(0.625)$ & $25704(0.690)$ \\
\hline$Q^{2}(30)$ & $24.540(0.747)$ & 26.284(0.661) & $25274(0.712)$ \\
\hline \multicolumn{4}{|c|}{ ARMA $(0,1)-G A R C H-M(1,1)$} \\
\hline Parameter & Normal & t-Student & GED \\
\hline$\omega$ & $0.050(0.000)$ & $0.044(0.000)$ & $0.047(0.000)$ \\
\hline$\alpha_{1}$ & $0.111(0.000)$ & $0.117(0.000)$ & $0.115(0.000)$ \\
\hline \multirow[t]{2}{*}{$\beta_{1}$} & $0.856(0.000)$ & $0.856(0.000)$ & $0.855(0.000)$ \\
\hline & & D.O.F $=9.745(0.000)$ & $\mathrm{PAR}=1.523(0.000)$ \\
\hline LL & -7557.204 & -7499.085 & -7507.436 \\
\hline Jarque-Bera & $553.5764(0.000)$ & $615.2196(0.000)$ & $585.4903(0.000)$ \\
\hline $\mathrm{ARCH}(30)$ & 24883(.0.730) & $26.859(0.630)$ & $25.678(0.691)$ \\
\hline $\mathrm{Q}^{2}(30)$ & $24.623(0.743)$ & $26.190(0.665)$ & $25.249(0.713)$ \\
\hline
\end{tabular}

Note. 1.Values in parentheses denote the $p$-values. 2. LL is the value of the log-likelihood. 
Table 8c. Estimated ARCH-GARCH-GARCH-M models for the daily returns of Sweden

\begin{tabular}{|c|c|c|c|}
\hline \multicolumn{4}{|c|}{ ARMA(0,3)-ARCH $(1,0)$} \\
\hline Parameter & Normal & t-Student & GED \\
\hline$\omega$ & $1.4888(0.000)$ & $1.515(0.000)$ & $1.452(0.000)$ \\
\hline \multirow{2}{*}{$\alpha_{1}$} & $0.317(0.000)$ & $0.349(0.000)$ & $0.323(0.000)$ \\
\hline & & D.O.F $=4.377(0.000)$ & $\mathrm{PAR}=1.186(0.000)$ \\
\hline LL & -13013.86 & -12645.75 & -12674.25 \\
\hline Jarque-Bera & $2991.354(0.000)$ & $3154.959(0.000)$ & $3118.569(0.000)$ \\
\hline $\mathrm{ARCH}(1)$ & $3.749(0.052)$ & $5.957(0.014)$ & $5.037(0.024)$ \\
\hline$Q^{2}(1)$ & $3.751(0.053)$ & $5.960(0.015)$ & $5.040(0.025)$ \\
\hline \multicolumn{4}{|c|}{ ARMA(0,3)-GARCH(1,1) } \\
\hline Parameter & Normal & t-Student & GED \\
\hline$\omega$ & $0.038(0.000)$ & $0.025(0.000)$ & $0.030(0.000)$ \\
\hline$\alpha_{1}$ & $0.097(0.000)$ & $0.095(0.000)$ & $0.096(0.000)$ \\
\hline \multirow[t]{2}{*}{$\beta_{1}$} & $0.884(0.000)$ & $0.894(0.000)$ & $0.890(0.000)$ \\
\hline & & D.O.F $=9.038(0.000)$ & $\mathrm{PAR}=1.499(0.000)$ \\
\hline LL & -12242.42 & -12109.21 & -12145.77 \\
\hline Jarque-Bera & $2594.030(0.000)$ & $3443.449(0.000)$ & $3004.152(0.000)$ \\
\hline $\mathrm{ARCH}(30)$ & $11.953(0.998)$ & $16.746(0.975)$ & $14.541(0.992)$ \\
\hline $\mathrm{Q}^{2}(30)$ & $11.986(0.999)$ & 16.301(0.980) & $14.378(0.993)$ \\
\hline \multicolumn{4}{|c|}{ ARMA $(0,3)$-GARCH-M $(1,1)$} \\
\hline Parameter & Normal & t-Student & GED \\
\hline$\omega$ & $0.038(0.000)$ & $0.025(0.000)$ & $0.030(0.000)$ \\
\hline$\alpha_{1}$ & $0.097(0.000)$ & $0.095(0.000)$ & $0.096(0.000)$ \\
\hline \multirow[t]{2}{*}{$\beta_{1}$} & $0.883(0.000)$ & $0.894(0.000)$ & $0.890(0.000)$ \\
\hline & & D.O.F=9.016(0.000) & $\mathrm{PAR}=1.498(0.000)$ \\
\hline LL & -12242.21 & -12109.09 & -12145.69 \\
\hline Jarque-Bera & $2567.730(0.000)$ & $3465.321(0.000)$ & 3020.694(0.000) \\
\hline $\mathrm{ARCH}(30)$ & $11.895(0.998)$ & $16.785(0.975)$ & $14.581(0.991)$ \\
\hline$Q^{2}(30)$ & $11.929(0.999)$ & $16.345(0.980)$ & $14.420(0.993)$ \\
\hline
\end{tabular}

Note. 1.Values in parentheses denote the $p$-values. 2. LL is the value of the log-likelihood.

Table 8d. Estimated ARCH-GARCH-GARCH-M models for the daily returns of Finland

\begin{tabular}{|c|c|c|c|}
\hline \multicolumn{4}{|c|}{ ARMA(0,1)-ARCH $(1,0)$} \\
\hline Parameter & Normal & t-Student & GED \\
\hline$\omega$ & $1.586(0.000)$ & $1.673(0.000)$ & $1.565(0.000)$ \\
\hline \multirow[t]{2}{*}{$\alpha_{1}$} & $0.262(0.000)$ & $0.275(0.000)$ & $0.261(0.000)$ \\
\hline & & D.O.F=4.206(0.000) & $\mathrm{PAR}=1.161(0.000)$ \\
\hline LL & -6490.810 & -6317.607 & -6318.631 \\
\hline Jarque-Bera & $1053.977(0.000)$ & $1051.303(0.000)$ & $1050.031(0.000)$ \\
\hline $\mathrm{ARCH}(1)$ & $4.779(0.028)$ & $4.711(0.030)$ & $4.949(0.026)$ \\
\hline $\mathrm{Q}^{2}(1)$ & $4.784(0.029)$ & $4.716(0.030)$ & $4.954(0.026)$ \\
\hline \multicolumn{4}{|c|}{ ARMA(0,1)-GARCH(1,1) } \\
\hline Parameter & Normal & t-Student & GED \\
\hline$\omega$ & $0.019(0.000)$ & $0.016(0.000)$ & $0.018(0.000)$ \\
\hline$\alpha_{1}$ & $0.078(0.000)$ & $0.078(0.000)$ & $0.078(0.000)$ \\
\hline \multirow[t]{2}{*}{$\beta_{1}$} & $0.911(0.000)$ & $0.913(0.000)$ & $0.912(0.000)$ \\
\hline & & D.O.F=11.939(0.000) & $\mathrm{PAR}=1.598(0.000)$ \\
\hline LL & -6043.635 & -6023.131 & -6021.973 \\
\hline Jarque-Bera & $80.132(0.000)$ & $83.137(0.000)$ & $81.579(0.000)$ \\
\hline $\mathrm{ARCH}(1)$ & $1.387(0.238)$ & $1.228(0.267)$ & $1.303(0.253)$ \\
\hline $\mathrm{Q}^{2}(1)$ & $1.389(0.239)$ & $1.230(0.267)$ & $1.304(0.253)$ \\
\hline \multicolumn{4}{|c|}{$\operatorname{ARMA}(0,1)$-GARCH-M $(1,1)$} \\
\hline Parameter & Normal & t-Student & GED \\
\hline$\omega$ & $0.019(0.000)$ & $0.016(0.000)$ & $0.018(0.000)$ \\
\hline$\alpha_{1}$ & $0.079(0.000)$ & $0.078(0.000)$ & $0.078(0.000)$ \\
\hline \multirow[t]{2}{*}{$\beta_{1}$} & $0.911(0.000)$ & $0.913(0.000)$ & $0.912(0.000)$ \\
\hline & & D.O.F=11.966(0.000) & $\mathrm{PAR}=1.599(0.000)$ \\
\hline LL & -6043.226 & -6023.118 & -6023.968 \\
\hline Jarque-Bera & $76.780(0.000)$ & $82.487(0.000)$ & $81.195(0.000)$ \\
\hline $\mathrm{ARCH}(1)$ & $1.452(0.228)$ & $1.240(0.265)$ & $1.311(0.252)$ \\
\hline $\mathrm{Q}^{2}(1)$ & $1.453(0.228)$ & $1.242(0.265)$ & $1.312(0.252)$ \\
\hline
\end{tabular}

Note. 1.Values in parentheses denote the $p$-values. 2. LL is the value of the log-likelihood. 
The last tables presented us the evaluations and the standard errors for the parameters with the value of log-likelihood function, as well as the tests of normality, autocorrelation and conditional heteroscedasticity. The result of each table revealed the statistical significance of coefficients, in every country, model and distribution. Also, no autocorrelation or conditional heteroscedasticity issue is found. Furthermore, models ARMA(0,1)-GARCH-M(1,1) models, and model ARMA(0,3)-GARCH-M(1,1) in case of Sweden, are the ones with the max Log Likelihood value using the t-Student distribution. Therefore, these models can be used for forecasting.

\section{Forecasting}

In forecasting the Nordic stock markets using the models $\operatorname{ARMA}(0,1)-\operatorname{GARCH}-\mathrm{M}(1,1)$ and ARMA(0,3)-GARCH-M $(1,1)$ we applied both the dynamic and static process. The dynamic process forecasts the time periods after the first time period of the sample, using the last forecast values from the lags of the dependent variable and the ARMA terms. This process is known as n-step ahead forecasts. The static process uses real, and not forecasted values, of the dependent variable. This process is known as one step- ahead forecast.

In Figures 3, 4, 5 and 5 we present the criterions of the evaluation of stock markets forecasting using the dynamic and static process, respectively.

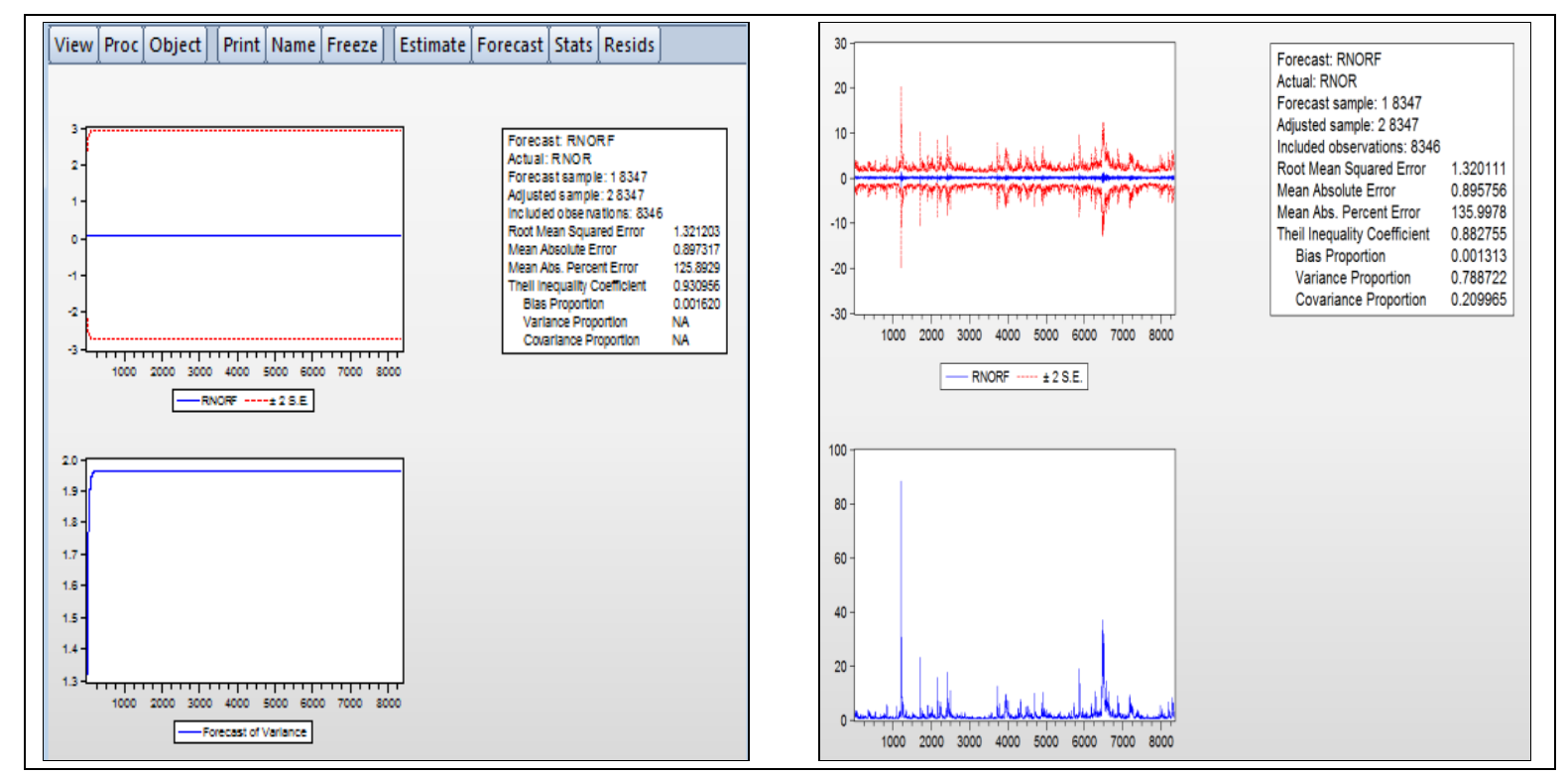

Figure 3. Dynamic and static forecast of the daily returns of Norwegian stock

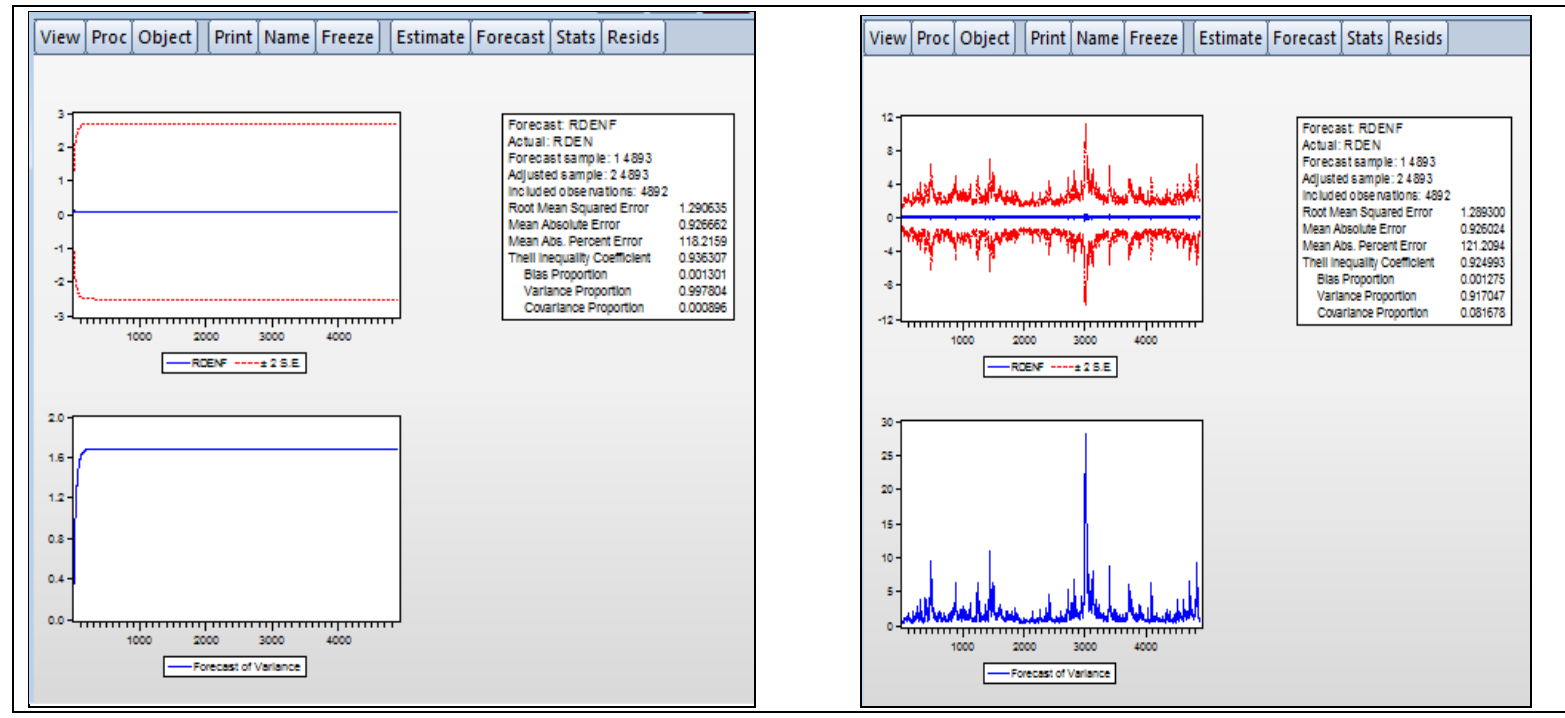

Figure 4. Dynamic and static forecast of the daily returns of Danish stock 


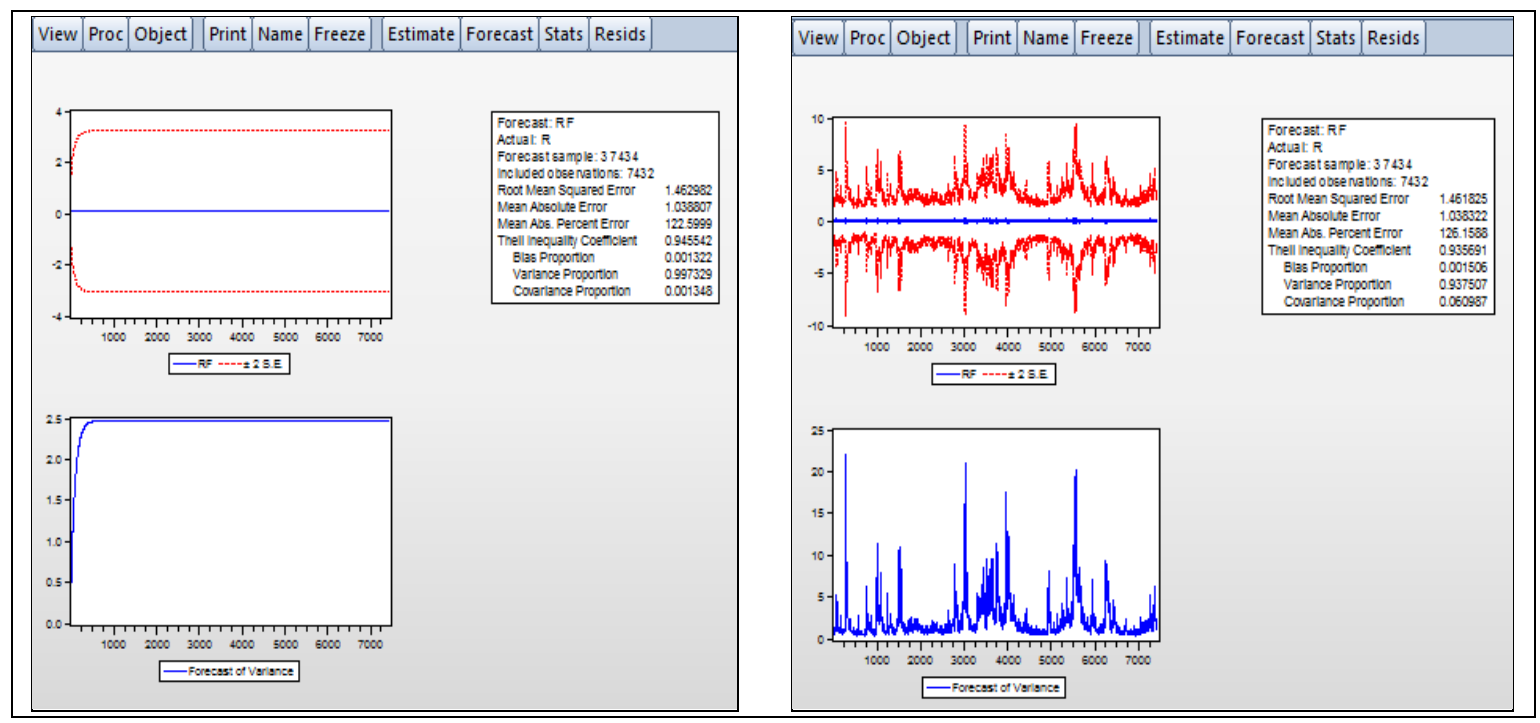

Figure 5. Dynamic and static forecast of the daily returns of Swedish stock

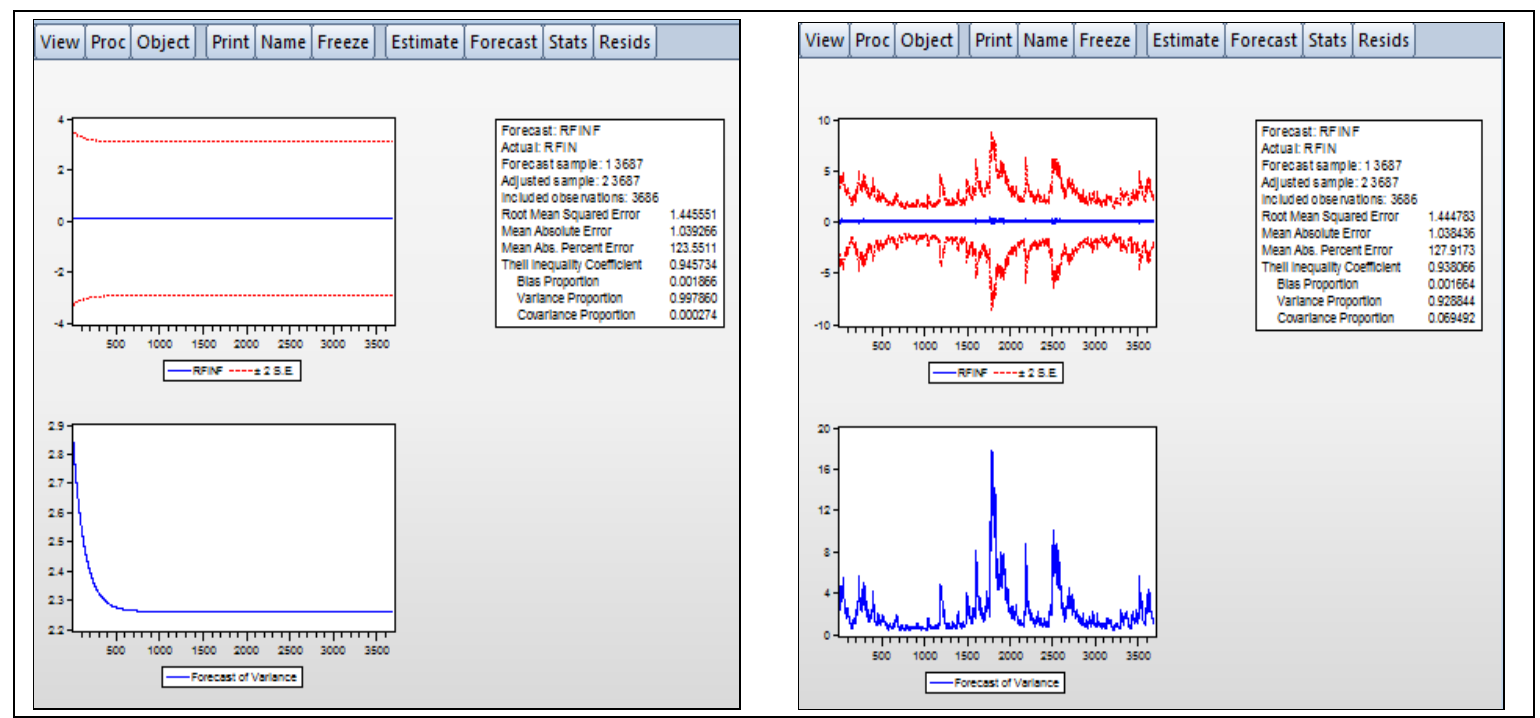

Figure 6. Dynamic and static forecast of the daily returns of Finnish stock

Based on the diagrams above we observe that static process gives better results than the dynamic one in each of the researched stock market (Theil index is lower in static process). But the fact that the Theil index is close to number one indicates that there is no appropriate forecast for the researched model.

\section{Discussion and Conclusion}

This study aims at modeling the volatility and the secondary effects at the four Nordic stock exchanges. The results indicated that each of the markets is well described by an ARMA( 0,1$)$-GARCH-M(1,1) model except that of Sweden which model ARMA(0,3)-GARCH-M(1,1) describes it best. Each market's returns and volatilities are strongly dependent on their own past values. Linear dependence is probably due to the presence of a time-varying risk premium or in a form of market ineffectiveness. Volatility in each one indicated that the ill news is stronger than good news. Research of volatility and returns of each market, is motivated by the ongoing discussion related to the enactment of common Nordic stock market among Nordic countries. This merging will create the fourth biggest stock exchange market in Europe, after London, Paris and Frankfurt.

\section{References}

Berndt, E., Hall, B., Hall, R., \& Hausman, J. (1974). Estimation and Inference in Nonlinear Structural Models. Annals of Economic and Social Measurement, 3, 653-665. Retrieved from http://EconPapers.repec.org/RePEc:nbr:nberch:10206 
Black, F., \& Scholes, M. (1973). The Pricing of Options and Corporate Liabilities. Journal of Political Economy, 81(3), 637-654. https://doi.org/10.1086/260062

Bollerslev, T. (1986). Generalized Autoregressive Conditional Heteroscedasticity. Journal of Econometrics, 31, 307-327. https://doi.org/10.1016/0304-4076(86)90063-1

Booth, G. G., Martikainen, T., \& Tse, Y. (1997). Price and Volatility Spillovers in Scandinavian Stock Markets. Journal of Banking \& Finance, 21(6), 811-823. https://doi.org/10.1016/S0378-4266(97)00006-X

Børs, O. (2016). Equity indices / Market data / Products and services / Oslo Børs / Home - Oslo Børs. Retrieved from https://www.oslobors.no/ob_eng/Oslo-Boers/Products-and-services/Market-data/Equity-indices

Dickey, D. A., \& Fuller, W. A. (1979). Distributions of the Estimators for Autoregressive Time Series with a Unit Root. Journal of American Statistical Association, 74(366), 427-431. https://doi.org/10.2307/2286348

Dickey, D. A., \& Fuller, W. A. (1981). Likelihood Ratio Statistics for Autoregressive Time Series with a Unit Root. Econometrica, 49(4), 1057-1072. https://doi.org/10.2307/1912517

Engle, R. F. (1982). Autoregressive Conditional Heteroscedasticity with Estimates of the Variance of United Kingdom Inflation. Econometrica, 50(4), 987-1007. https://doi.org/10.2307/1912773

Engle, R. F., Lilien, D. M., \& Robins, R. P. (1987). Estimating Time Varying Risk Premium in the Term Structure: The Arch-M Model. Econometrica, 55(2), 391-407. https://doi.org/10.2307/1913242

Eun, C., \& Shim, S. (1989). International Transmission of Stock Market Movement. The Journal of Financial Quantitative Analysis, 24(2), 241-255. https://doi.org/10.2307/2330774

Hamao, Y. R., Masulis, R. W., \& Ng, V. K. (1990). Correlations in Price Changes and Volatility Across International Stock Markets. Review of Financial Studies, 3, 281-307. https://doi.org/10.1093/rfs/3.2.281

Hyytinen, A. (1999). Stock Return Volatility on Scandinavian Stock Markets and the Banking Industry: Evidence from the Years of Financial Liberalisation and Banking Crisis. Bank of Finland Research Discussion Paper 19 (1999). Retrieved from https://helda.helsinki.fi/bof/bitstream/handle/123456789/7861/91744.pdf?sequence

Lee, H. S. (2004). International transmission of stock market movements: A wavelet analysis. Applied Economics Letters, 11, 197-201. https://doi.org/10.1080/1350485042000203850

Ljung, G. M., \& Box, G. E. P. (1978). On a Measure of a Lack of Fit in Time Series Models. Biometrika, 65(2), 297-303. https://doi.org/10.1093/biomet/65.2.297

MacKinnon, J. G. (1996). Numerical Distribution Functions for Unit Root and Cointegration Tests. Journal of Applied Econometrics, 601-618. https://doi.org/10.1002/(SICI)1099-1255(199611)11:6<601::AID-JAE417>3.0.CO;2-T

Nasdaqomxnordic.com. (2016a). Historical prices OMXC20, OMX Copenhagen 20, (DK0016268840) $\begin{array}{llll}N A S D A Q & O M X & \text { NORDIC. } & \text { Retrieved }\end{array}$ http://www.nasdaqomxnordic.com/indexes/historical_prices?Instrument=DK0016268840

Nasdaqomxnordic.com. (2016b). Historical prices OMXH25, OMX Helsinki 25, (FI0008900212) - NASDAQ OMX NORDIC. Retrieved from http://www.nasdaqomxnordic.com/indexes/historical_prices?Instrument=FI0008900212

Nasdaqomxnordic.com. (2016c). Historical prices OMXS30, OMX Stockholm 30 Index, (SE0000337842) NASDAQ OMX NORDIC. $\quad$ Retrieved from http://www.nasdaqomxnordic.com/indexes/historical_prices?Instrument=SE0000337842

Newey, W. K., \& West, K. D. (1994). Automatic lag selection in covariance matrix estimation. Review of Economic Studies, 61(4), 631-654. https://doi.org/10.2307/2297912

$\mathrm{Ng}$, A. (2000). Volatility Spillover Effects from Japan and the U.S. to the Pacific Basin. Journal of International Money and Finance, 19, 207-233. https://doi.org/10.1016/S0261-5606(00)00006-1

Phillips, P. C. B., \& Perron, P. (1998). Testing for a Unit Root in Time Series Regression. Biometrika, 75, 335-346. https://doi.org/10.1093/biomet/75.2.335

Prashant, J. (2014). Volatility Interactions among India and US Stock Markets. Case Studies in Business and Management, 1(1), 107-117. https://doi.org/10.5296/csbm.v1i1.5830

Theil, H. (1967). Economics and Information Theory. Chicago: Rand McNally and Company. 
Thenmozh, M., \& G. Sarath, C. (2016). Forecasting stock returns based on information transmission across global markets using support vector machines. Neural Computing and Applications, 27(4), 805-824. https://doi.org/10.1007/s00521-015-1897-9

Trang, N. L., \& Makoto, K. (2010). International transmission of stock returns: Mean and volatility spillover effects in Indonesia and Malaysia. The International Journal of Business and Finance Research, 4(1), 115-131. International Transmission of Stock Returns Mean and Volatility Spillover Effects in Indonesia and Malaysia. Retrieved from https://www.researchgate.net/publication/228241200

\section{Copyrights}

Copyright for this article is retained by the author(s), with first publication rights granted to the journal.

This is an open-access article distributed under the terms and conditions of the Creative Commons Attribution license (http://creativecommons.org/licenses/by/4.0/). 